\title{
Delirium Research in India: A Systematic Review
}

\author{
Sandeep Grover ${ }^{1}$ Sanjana Kathiravan ${ }^{1, \odot}$ Devakshi Dua ${ }^{1}$
}

${ }^{1}$ Department of Psychiatry, Postgraduate Institute of Medical Education and Research, Chandigarh, India
Address for correspondence Sandeep Grover, MD, Department of Psychiatry, Postgraduate Institute of Medical Education and Research, Chandigarh 160012, India (e-mail: drsandeepg2002@yahoo.com).

J Neurosci Rural Pract 2021;12:236-266.

\begin{abstract}
Keywords

- delirium

- India

- outcome
\end{abstract}

\section{Introduction}

Delirium is an acute medical emergency, with psychiatric manifestations, which is seen across different treatment settings, with higher prevalence in intensive care units (ICUs) and palliative care setting. It is characterized by poor attention, disturbances in other cognitive functions, motoric alteration, disturbance in sleep, and psychotic symptoms. The prevalence of delirium varies across different settings, with rates as high as $80 \%$ among patients admitted in intensive care units (ICUs) and palliative care setting. ${ }^{1}$ From an organ failure point of view, delirium represents acute brain failure, occurring due to various causes. ${ }^{2,3}$ The various contributing factors for delirium can be broadly categorized as risk or predisposing and the precipitating or etiological factors. ${ }^{4}$ It is the combination of the risk and the precipitating factors which determine the manifestation of delirium. ${ }^{5}$ Patients, who are at high risk, may require minor precipitating factors for the development of delirium, whereas those who have lower risk factors may require more or severe precipitating factors published online

April 1, 2021
DOI https://doi.org/

10.1055/s-0041-1725211 ISSN 0976-3147. (c) 2021. Association for Helping Neurosurgical Sick People.

This is an open access article published by Thieme under the terms of the Creative Commons Attribution-NonDerivative-NonCommercial-License, permitting copying and reproduction so long as the original work is given appropriate credit. Contents may not be used for commercial purposes, or adapted, remixed, transformed or built upon. (https://creativecommons.org/licenses/by-nc-nd/4.0/).

Thieme Medical and Scientific Publishers Pvt. Ltd. A-12, 2nd Floor, Sector 2, Noida-201301 UP, India 
for the development of delirium..$^{5}$ As a disorder, delirium is associated with significant negative consequences for the patients and their families in terms of increased mortality, longer duration of ICU and inpatient stay, higher treatment cost, long-term cognitive deficits, a higher risk of developing dementia, and high level of distress to the patients and caregivers. ${ }^{6}$

Although it is seen across all the medical-surgical settings, it is often underrecognized and undertreated. Some of the developed countries have recognized the importance of early identification and prevention of delirium in various treatment settings. ${ }^{7.8}$ Many authors have developed bedside assessment instruments to detect delirium at the earliest and have also developed various intervention packages, such as the Hospital Elder Life Program (HELP) ${ }^{9}$ and Assess, Prevent, and Manage Pain, Both Spontaneous Awakening Trials (SAT) and Spontaneous Breathing Trials (SBT); choice of analgesia and sedation; and the Delirium: Assess, Prevent, and Manage Early mobility and Exercise, and Family engagement and empowerment $(\mathrm{ABCDEF})^{10}$ bundle for early detection, prevention, and management of delirium.

Considering its ubiquitousness across all clinical specialties and underrecognition, it is important to understand awareness about delirium. One of the ways to address the issue is to look at the research outcome on the topic. Till today, there is no systematic review focusing on the research output on delirium from India. Evaluating the research output can help in understanding the current level of research and deficits in research. This can help in planning future research on the topic. Accordingly, this systematic review attempted to evaluate the research on delirium from India.

\section{Methodology}

For this systematic review, literature was searched in various search engines, that is, PubMed and Google Scholar, by using the following terms: "delirium," "delirious," "delirium tremens," "India," and "organic brain syndrome" in different combinations in December 2019. No filters were used. Additional searches were performed by doing hand searches of the reference list of the published articles to identify more articles. Additionally, the table of content of online issues of various psychiatric and anesthesia journals (irrespective of the indexing status) published from India, were specifically searched for studies focusing on delirium.

To be included in the review, the published papers were required to have the words "delirium," "delirious," or "delirium tremens" in the title. However, if the studies did not include these terms in the title but the primary focus of the study was delirium, then these papers were included in the review. Studies describing the psychiatric referral pattern, but which did not focus on the delirium, but in general described the prevalence of delirium in psychiatric referrals, were excluded. Data published only as abstracts of the national conferences were also excluded.

Internet and hand searches yielded 305 articles. -Fig. 1 shows the selection of the articles. Full manuscripts of these articles were reviewed by D.D. and S.K. Out of these articles, 151 had the terms "delirium," "delirious," "delirium tremens" in the title and these were included for the review (-Fig. 2). Additionally, 14 articles were included for the review, although these did not have these terms in the title but had delirium as one of the major outcome parameters. A majority $(n=144 ; 87.3 \%)$ of these articles were available in the PubMed search (-Fig. 2).

\section{Results}

Out of the 165 articles, it was seen that the majority (85.5\%, $n=141$ ) of the papers were published in the last one decade (2011-2019), and this was followed by 23(13.9\%) articles published during the year 2001 to 2010. There was only one article (0.6\%) on delirium before 2001, arising from India. Again, in the years 2011 to 2019, there were at least 10 articles published every year (-Fig. 3). A majority (87.3\%) of the articles were published in the PubMed indexed journals and about one-third (31.5\%) of these articles had nonpsychiatrist as an author. In terms of the type of papers, majority of the papers were original articles ( $n=81$, one of which was in the form of a letter to the editor), ${ }^{11-91}$ and these were followed by, case reports $(n=58),{ }^{92-149}$ review articles $(n=10),{ }^{4,150-158}$ letter to the editor (not as case reports but as a communication; $n=13),{ }^{81,159-170}$ editorials $(n=2),{ }^{171,172}$ and one clinical practice guideline. ${ }^{173}$ In terms of the institutes, most (37.6\%, $n=62$ ) of the articles were from the Postgraduate Institute of Medical Education and Research (PGIMER), Chandigarh, and this was followed by National Institute of Mental Health and Neurosciences (NIMHANS), Bengaluru $(n=6)$.

In terms of the original paper, out of the 81 papers, a majority ( $n=50 ; 61.7 \%$ ) of these were published in journals published from outside India. About two-fifths $(n=33 ; 40.7 \%)$ of the original articles had nonpsychiatrists as an author and about one-fourth ( $n=19 ; 23.5 \%$ ) of these studies focused on ICU patients or ICU health care workers.

As across the globe, the prevalence and incidence of delirium, in studies from India have also varied depending on the study setting ( - Table 1) ${ }^{11-36}$ Majority of the studies have assessed the incidence and prevalence of delirium have relied on the Diagnostic and Statistical Manual of Mental Disorders, fourth edition (DSM-IV)/DSM-IV text revision (TR) criteria. 15,17,19,20,23-27,29-31 However, some of the studies have used confusion assessment method (CAM)/CAMICU. ${ }^{13,14,16,18,33,34}$ The prevalence rates in various ICUs have varied from 16.1 to $68.2 \%{ }^{15-17,19,20,23}$ Similarly, the incidence of delirium in various ICUs ranges from 8 to $59.6 \%$. $^{15,17-22}$

One of the studies evaluated delirium in general medical inpatients and reported the prevalence rate to be $19 \%,{ }^{11}$ whereas another study that focused on postoperative patients reported a prevalence rate of $4 \%{ }^{32}$ One study reported a prevalence of delirium in referrals of consultation liaison psychiatry (CLP) setting and estimated the prevalence to be $33.96 \% .^{12}$ The same study extrapolated the prevalence to all the inpatients and estimated the prevalence to be $0.44 \%{ }^{12}$ However, this could be an 

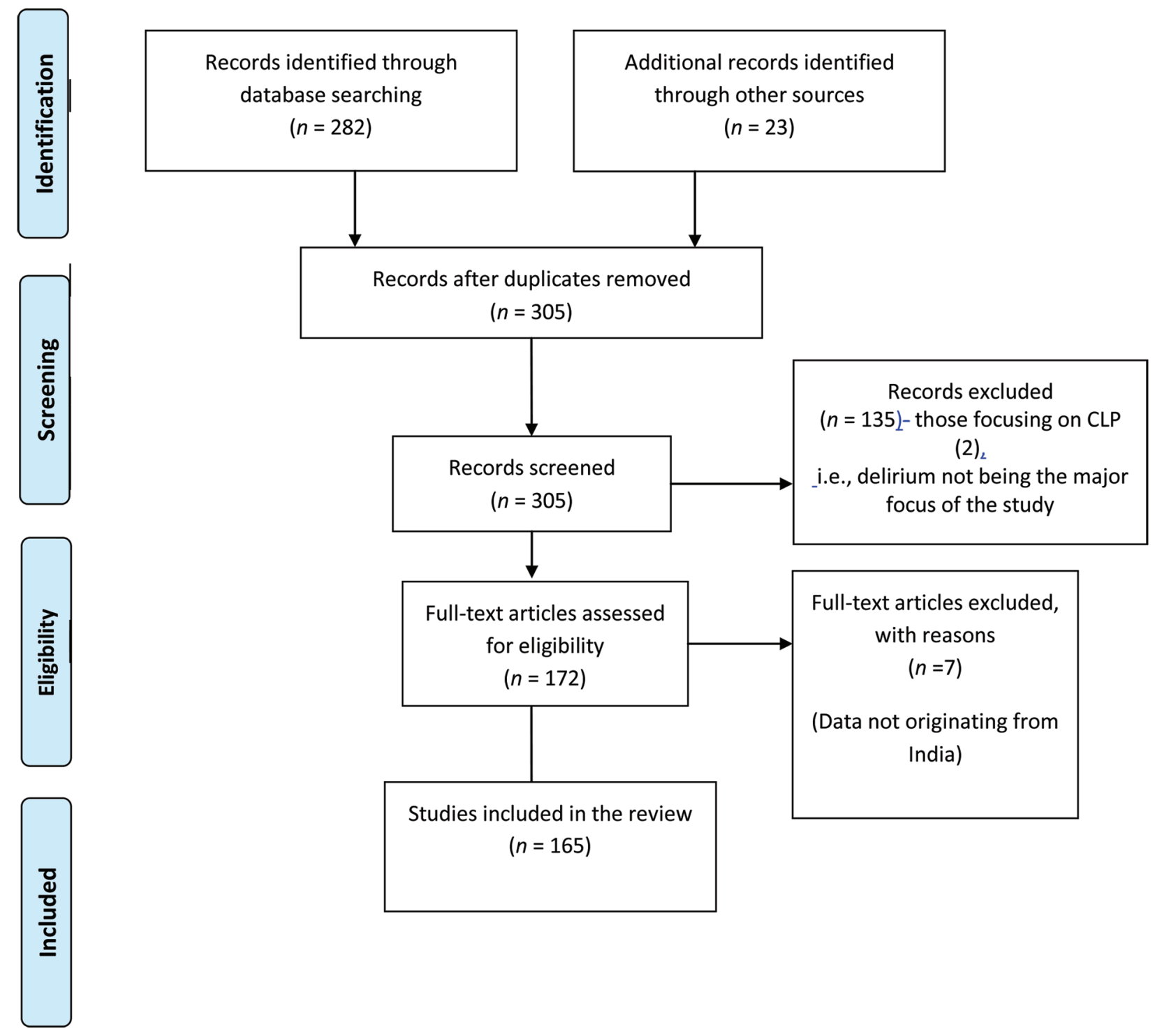

Fig. 1 PRISMA diagram showing selection of studies. PRISMA, preferred reporting items for systematic reviews and meta-analyses.

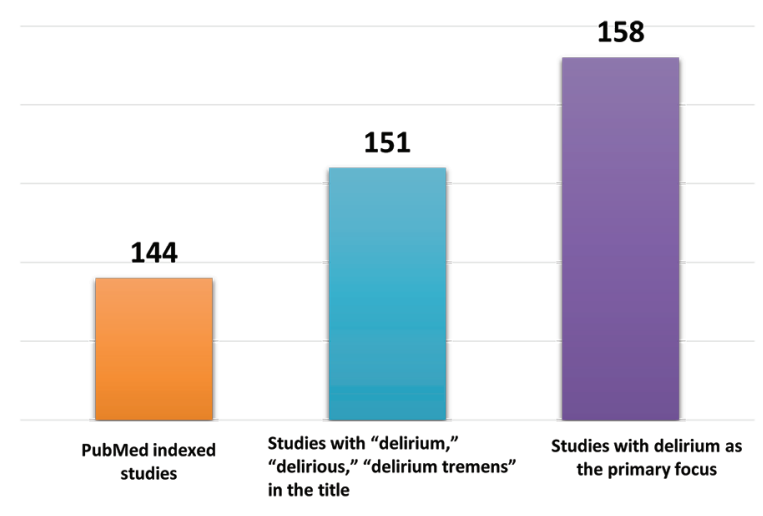

Fig. 2 Number of articles in PubMed search, having the word delirium and related terms in the title, and studies with delirium being the primary focus of the study. underestimation, as many patients who develop delirium are not referred to the CLP services.

Studies have also reported the inpatient mortality rates for patients with delirium and the same has varied from 6.6 to $30.7 \%{ }^{12,14,17-20,24-31}$ However, only occasional studies have compared the mortality data with all the inpatients, who did not develop delirium. One of the studies reported that the inpatient mortality rate for patients with delirium was $12.1 \%$ and was higher compared with those patients who were not referred to the CLP services for delirium. ${ }^{27}$ Occasional studies have reported long-term mortality in patients of delirium, after 1 to 6 months of inpatient care and the rates have varied from 15.9 to $34.6 \%{ }^{13,18,27}$

A total of 23 studies ( - Table 2 ) ) $^{15,24-29,31,37-51}$ have evaluated the symptom profile of delirium and most of these studies have relied on the Delirium Rating Scale Revised-1998 (DRSR-98). The majority of these studies have focused on patients 


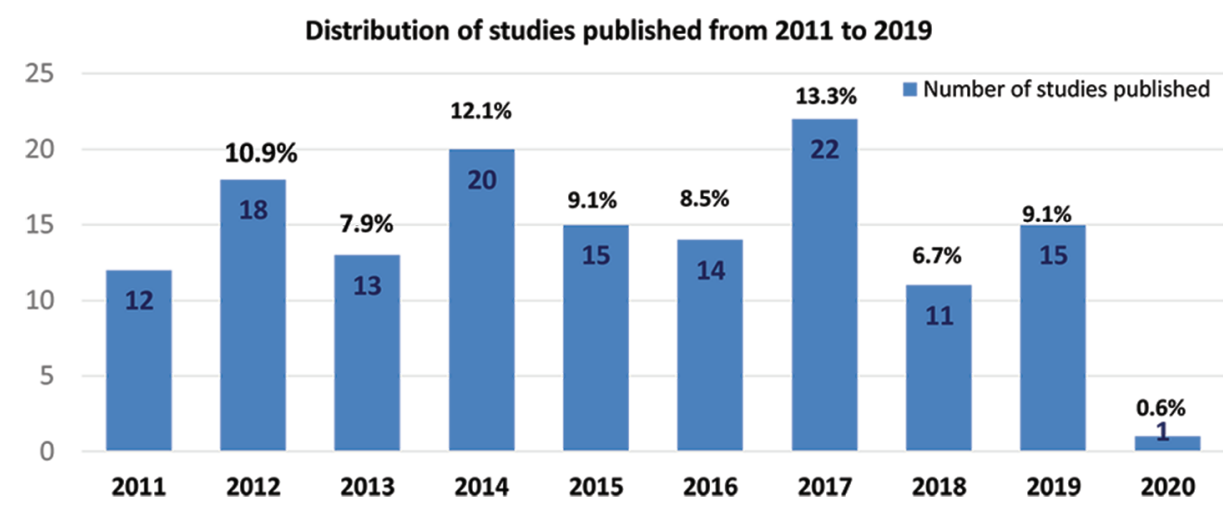

Fig. 3 Number of articles published in each year in last one decade.

seen by CLP services, with occasional studies focusing on ICU patients. Some of the studies have also specifically focused on children, ${ }^{25,49}$ elderly, ${ }^{37,41,44,46}$ and those with alcohol-withdrawal delirium (AWD). ${ }^{31}$ In general, these studies suggest that disturbance in attention, disorientation, and other cognitive functions are present in a majority of the patients. In terms of specific items of DRS-R-98, studies that have been done in CLP setting, in general, report higher frequency of motor agitation, whereas studies in ICUs suggest a higher frequency of motor retardation. The studies which have compared people of different age groups suggest that there are minor variation in the symptom profile of delirium in children, adult, and elderly. 25,37,41,44,46,49

Many studies have evaluated the factor structure of the symptom profile of delirium ( Table 3). . $5,22,28,31,37-39,41,42,52$ As with the symptom profile, most of these studies have again relied on DRS-R-98, ${ }^{15,28,31,37,39,41,52}$ with some of the studies using the Memorial Delirium Assessment Scale (MDAS) 22,52 and Intensive Care Delirium Screening Checklist ICDSC scales. ${ }^{38}$ One study combined items of DRS-R98, CSE, and MDAS. ${ }^{52}$ Most of these studies have consistently recognized a three-factor solution, ${ }^{15,28,31,37,39,41,42}$ with some differences in the distribution of symptoms across different factors. In the majority of these studies, the cognitive symptoms load on one factor, the motoric and psychotic symptoms load on to the same factor, and the third factor consists of language and thought process abnormalities. The motoric- and psychotic-symptom factors more consistently load on to the same factor across different studies. One study which compared the patients of pure alcohol withdrawal and those with alcohol withdrawal along with some other etiologies contributing to delirium reported subtle differences in the factor structure between the two groups. $^{31}$

Studies have also evaluated motoric subtypes of delirium and have come up with different prevalence rates, which are mostly influenced by the study setting and the assessment scales ( $\boldsymbol{- T a b l e ~ 4 ) . ~}{ }^{14,15,18,23,25,29,38,44,47,51,53-55}$ Most of the studies have relied upon the Delirium Motor Symptom Scale (DMSS)/ amended DMSS. $15,25,29,44,47,51,53$ The prevalence rate of hypoactive delirium in ICUs $s^{15,18,23,51}$ has varied from 26 to $65 \%$, for mixed subtype, ranges from 10.2 to $29 \%$, and for hyperactive subtype, ranges from 15.7 to $56.8 \%$. The prevalence rate of hyperactive delirium is significantly more in studies evaluating the patients in CLP services setting and medical-surgical wards with prevalence varying from 25 to $70 \%$ and the prevalence of hypoactive delirium range from 7.3 to $65 \%$. $14,25,29,38,44,47,53-55$ Occasional studies have reported no subtype for approximately $5 \%$ of cases. ${ }^{29,51}$

\section{Studies Evaluating other Aspects of Delirium in ICU Patients}

Besides focusing on the incidence, prevalence, symptom profile, factor structure, and mortality in patients with delirium, studies involving ICU patients have also evaluated the risk factors and have validated scales such as ICDSC, MDAS, and CAM-ICU (- Table 5). ${ }^{18-20,22,23,52,56,57}$ These studies suggest that these scales have good psychometric properties in ICU patients for detecting delirium. ${ }^{22,23,52}$ The cut-off score of 3 or more for ICDSC and a cut-off score of 10 or more for MDAS have been found to have good psychometric properties for delirium. ${ }^{22,52}$ One study which compared CAM-ICU and ICSDC suggests that compared with ICDSC, CAM-ICU has higher sensitivity and diagnostic odds ratio $(84 \%, 86.1) .{ }^{23}$ One of the studies evaluated the incidence and prevalence of delirium in patients admitted to ICU and compared these figures with the psychiatric referral rates and reported a wide gap in the actual incidence and prevalence of delirium in ICU patients and those referred to psychiatry CLP services. ${ }^{56}$ Studies that have evaluated the risk factors, have, in general, reported mechanical ventilation to be an important risk factor for delirium. ${ }^{18,19}$ Some of these studies also suggest that compared with those who do not develop delirium, those with delirium have higher mortality rate and significantly longer duration of ICU stay. ${ }^{18-20}$

\section{Studies Focusing on Patients with Alcohol-Withdrawal Delirium}

Five studies have primarily focused on patients with AWD (-Table 5). . $^{30,31,58-60}$ One study evaluated the service model for patients with AWD and reported that compared with 
Table 1 Prevalence and incidence of delirium

\begin{tabular}{|c|c|c|c|c|c|c|c|}
\hline Study (year) & $\begin{array}{l}\text { Treatment } \\
\text { setting }\end{array}$ & $\begin{array}{l}\text { Diagnostic } \\
\text { system used }\end{array}$ & $\begin{array}{l}\text { Sample } \\
\text { size }\end{array}$ & Prevalence & Incidence & $\begin{array}{l}\text { Inpatient } \\
\text { mortality }\end{array}$ & $\begin{array}{l}\text { Mortality at } \\
\text { follow-up }\end{array}$ \\
\hline \multicolumn{8}{|l|}{ Inpatient setting } \\
\hline $\begin{array}{l}\text { Khurana et al } \\
(2002)^{11}\end{array}$ & $\begin{array}{l}\text { General medical } \\
\text { inpatients }\end{array}$ & ICD-10 & 100 , elderly & $19 \%$ & $8 \%$ & & \\
\hline $\begin{array}{l}\text { Grover et al } \\
(2009)^{12}\end{array}$ & Inpatient & ICD-10 & $\begin{array}{l}238,777 \\
3,092^{a}\end{array}$ & $\begin{array}{l}0.44 \% \\
33.96 \%\end{array}$ & & $6.6 \%$ & \\
\hline Rai et al $(2014)^{13}$ & $\begin{array}{l}\text { Neurology } \\
\text { inpatient }\end{array}$ & CAM & 52 & & & & $\begin{array}{l}34.6 \% \text { ( } 1-3 \text { months } \\
\text { of } F / U \text { ) }\end{array}$ \\
\hline $\begin{array}{l}\text { Khurana et al } \\
(2011)^{14}\end{array}$ & Inpatient, elderly & CAM & 400 & $27.47 \%$ & & $14.75 \%$ & \\
\hline \multicolumn{8}{|l|}{ ICU setting } \\
\hline $\begin{array}{l}\text { Grover et al } \\
(2018)^{15}\end{array}$ & ICU & DSM-IVTR & 66 & $68.2 \%$ & $59.6 \%$ & & \\
\hline $\begin{array}{l}\text { Kumar et al } \\
(2016)^{16}\end{array}$ & ICU & CAM-ICU & 31 & $16.1 \%$ & - & - & \\
\hline $\begin{array}{l}\text { Grover et al } \\
(2014)^{17}\end{array}$ & $\mathrm{CCU}$ & DSM-IVTR & 152 elderly & $24.34 \%$ & $13.4 \%$ & $19.2 \%$ & \\
\hline $\begin{array}{l}\text { Jayaswal et al } \\
(2019)^{18}\end{array}$ & Medical ICU & $\begin{array}{l}\text { CAM-ICU } \\
\text { RASS }\end{array}$ & 280 & & $31.4 \%$ & $9.9 \%$ & 15.9 (1-month $\mathrm{F} / \mathrm{U})$ \\
\hline $\begin{array}{l}\text { Sharma et al } \\
(2012)^{19}\end{array}$ & $\mathrm{RICU}$ & DSM-IV & 140 & $53.6 \%$ & $24.4 \%$ & $30.7 \%$ & \\
\hline $\begin{array}{l}\text { Lahariya et al } \\
(2014)^{20}\end{array}$ & $\mathrm{CCU}$ & DSM-IV & 309 & $18.7 \%$ & $9.3 \%$ & $27 \%$ & \\
\hline $\begin{array}{l}\text { Bamalwa et al } \\
(2016)^{21}\end{array}$ & Cardiac ICU & & 50 & & $16 \%$ & & \\
\hline $\begin{array}{l}\text { Shyamsundar et } \\
\text { al }(2009)^{22}\end{array}$ & $\begin{array}{l}\text { Medical/cardiac } \\
\text { ICU }\end{array}$ & & 120 & & $10.3 \%$ & & \\
\hline $\begin{array}{l}\text { Barman et al } \\
(2018)^{23}\end{array}$ & $\begin{array}{l}\text { Multidisciplinary } \\
\text { ICU }\end{array}$ & DSM-IVTR & 310 & $45 \%$ & & & \\
\hline \multicolumn{8}{|c|}{ Consultation liaison setting } \\
\hline $\begin{array}{l}\text { Grover et al } \\
(2013)^{24}\end{array}$ & CLP & DSM-IV TR & 331 & - & - & $12.4 \%$ & \\
\hline $\begin{array}{l}\text { Grover et al } \\
(2014)^{25}\end{array}$ & CLP & DSM-IVTR & 49, CAP & & & $10 \%$ & \\
\hline $\begin{array}{l}\text { Grover et al } \\
(2019)^{26}\end{array}$ & CLP & DSM-IVTR & 103 & & & $10.7 \%$ & \\
\hline $\begin{array}{l}\text { Grover et al } \\
(2012)^{27}\end{array}$ & CLP & DSM-IVTR & 97 & & & $\begin{array}{l}12.1 \% \\
6.79 \%^{\mathrm{b}}\end{array}$ & $\begin{array}{l}27.83 \% \text { ( } 6 \text { months } \\
\text { of } F / U \text { ) }\end{array}$ \\
\hline $\begin{array}{l}\text { Grover et al } \\
(2012)^{28}\end{array}$ & CLP & ICD-10 & 109, elderly & & & $16.5 \%$ & \\
\hline $\begin{array}{l}\text { Grover et al } \\
(2014)^{29}\end{array}$ & CLP & DSM-IV TR & 321 & & & $10.3 \%$ & \\
\hline $\begin{array}{l}\text { Grover et al } \\
(2013)^{30}\end{array}$ & CLP, AWD & DSM-IVTR & 112 & & & $13.4 \%$ & \\
\hline $\begin{array}{l}\text { Grover et al } \\
(2016)^{31}\end{array}$ & CLP, AWD & DSM-IVTR & 112 & & & $13.4 \%$ & \\
\hline \multicolumn{8}{|c|}{ Surgery and postoperative setting } \\
\hline $\begin{array}{l}\text { Dhakharia et al } \\
(2017)^{32}\end{array}$ & $\begin{array}{l}\text { Postoperative } \\
\text { setting }\end{array}$ & & 824 & $4 \%$ & & & \\
\hline $\begin{array}{l}\text { Kumar et al } \\
(2017)^{33}\end{array}$ & $\begin{array}{l}\text { Postoperative } \\
\text { (cardiac surgery) }\end{array}$ & CAM-ICU & & & $17.5 \%$ & & \\
\hline $\begin{array}{l}\text { Chrispal et al } \\
(2010)^{34}\end{array}$ & $\begin{array}{l}\text { Delirium in patient } \\
\text { undergoing hip } \\
\text { fractures surgery }\end{array}$ & CAM & 81 & & $21 \%$ & & \\
\hline
\end{tabular}


Table 1 (continued)

\begin{tabular}{|l|l|l|l|l|l|l|l|}
\hline Study (year) & $\begin{array}{l}\text { Treatment } \\
\text { setting }\end{array}$ & $\begin{array}{l}\text { Diagnostic } \\
\text { system used }\end{array}$ & $\begin{array}{l}\text { Sample } \\
\text { size }\end{array}$ & Prevalence & Incidence & $\begin{array}{l}\text { Inpatient } \\
\text { mortality }\end{array}$ & $\begin{array}{l}\text { Mortality at } \\
\text { follow-up }\end{array}$ \\
\hline Miscellaneous & $\begin{array}{l}\text { Khanna et al } \\
(2018)^{35}\end{array}$ & $\begin{array}{l}\text { Pediatric patients } \\
\text { undergoing } \\
\text { ophthalmic exami- } \\
\text { nation under } \\
\text { sevoflurane }\end{array}$ & PAED scale & 100 & $24 \%$ & & \\
\hline $\begin{array}{l}\text { Sethi et al } \\
(2013)^{36}\end{array}$ & $\begin{array}{l}\text { Pediatric patients } \\
\text { undergoing cata- } \\
\text { ract surgery under } \\
\text { sevoflurane and } \\
\text { desflurane }\end{array}$ & PAED scale & 88 & $\begin{array}{l}18.18 \% \text { in the } \\
\text { sevoflurane } \\
\text { group } \\
20.45 \% \text { in the } \\
\text { desflurane } \\
\text { group }\end{array}$ & & & \\
\hline
\end{tabular}

Abbreviations: AWD, alcohol withdrawal delirium; CAM, confusion assessment method; CAP, children and adolescents; CLP, consultation liaison psychiatry; DSM-IV, Diagnostic and Statistical Manual of Mental Disorders, fourth edition; DSM-IV TR, DSM-IV text revision; F/U, follow-up; ICD, International Classification of Disease; ICU, intensive care unit; PAED, pediatric anesthesia emergency department. aPrevalence of delirium in psychiatric referrals.

bInpatient mortality rate of patients not referred to CLP services for delirium.

the emergency services treatment group alone, emergency services plus comprehensive inpatient addiction treatment group had fewer relapses. ${ }^{59}$ Other studies have focused on risk factors associated with $A W D,{ }^{58}$ symptom profile of delirium, ${ }^{30}$ and factor structure of symptom profile. ${ }^{31}$ One study evaluated the genetic variations associated with the development of delirium tremens and reported that delirium tremens was significantly associated with presence of $\mathrm{T}$ allele (GT and TT; [rs1824024]) of muscarinic cholinergic receptor 2 (CHRM2).60

\section{Studies Involving Patients Seen in Medical-Surgical Consultation Liaison Setting}

Maximum numbers of studies done in the medical-surgical setting ( - Table 5) $)^{12,13,24,25,29,40,41,44-46,48-50,54,55,61-68}$ have not been limited to any one particular ward. Available data suggest that delirium is the most common diagnosis made by the CLP team, ${ }^{12,62}$ diagnostic concordance of delirium between psychiatrists and physicians is low, ${ }^{62}$ and mortality of patients with delirium is more than those without delirium. The most common reason for referral of patients with delirium to CLP teams is abnormal behavior or patient's noncooperation for treatment. ${ }^{12}$

Factors that predict a delay in referral of patients with delirium include prevalent delirium at admission, sleep-wake disturbance, the specialty of referral, presence motor retardation, being admitted to medical ward/medical ICUs, and absence of comorbid axis- 1 psychiatry diagnoses. In terms of symptom/clinical profile, available data suggest that there are subtle differences between patients seen in medical-surgical wards and emergency setting. ${ }^{61}$ Available data also suggest subtle differences in the symptom profile of patients with different subtypes of delirium, ${ }^{25,44}$ patients of different age groups (children, adult, and elderly),, ${ }^{41,43,49,63}$ and those with and without premorbid cognitive deficits. ${ }^{46}$ In terms of symptom profile, available data also suggest that attention deficit is the core symptom of delirium. ${ }^{40}$ One study showed a prevalence of catatonic symptoms in about one-third of the patients with delirium. Inpatient mortality in patients with delirium is associated with lower age ( $<65$ years) and more frequent use of restraining before the development of delirium. ${ }^{24}$ Many studies have focused on the risk factors of delirium, and these studies have come up with some of the common risk and etiological factors, ${ }^{13,54,63,68}$ and other factors specific to treatment setting. ${ }^{24}$ One study validated the DMSS $^{64}$ and other amended the DMSS. ${ }^{65}$ Another study evaluated the concordance between DSM-IV and DSM-5 criteria and reported considerable variability depending on how the criteria are interpreted, with very strict adherence to the text detailing DSM-5, leading to a reduction in the number of cases diagnosed with delirium; however, when a more "relaxed" approach is used, DSM-5 criteria is comparable to DSM-IV criteria. ${ }^{66}$

\section{Studies Focusing on Postoperative Patients}

Studies that have focused on postoperative patients $(- \text { Table } 5)^{32,34,35}$ have mainly attempted to identify the risk factors for delirium in patients of cancers undergoing surgery, ${ }^{32}$ patients undergoing surgery for hip fracture, ${ }^{34}$ and children undergoing ophthalmic examination under general anesthesia with sevoflurane. ${ }^{35}$

\section{Studies Focusing on the Health Care Professionals}

Studies evaluating the opinion of the health care professionals (-Table 5) ${ }^{69-71}$ suggest that most of the ICU clinicians do not assess patients for delirium on regular basis, consider the prevalence rates of delirium, especially among those patients on mechanical ventilation to be lower than what is reported in the literature. In terms of assessment, those ICU clinicians, who assess patients for delirium, mostly rely on the CAM-ICU scale and use haloperidol for the management of delirium. ${ }^{69}$ Data also suggest that most of the ICU clinicians are aware of the importance of early mobilization of ICU patients but are not able to practice the same due to lack of support staff and safety concerns. One study, which evaluated the practice of $A B C D E F$ bundle across the globe and 


\begin{tabular}{|c|c|c|c|c|c|c|c|c|c|c|c|}
\hline 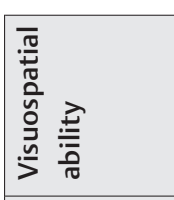 & $\hat{\phi}$ & $\overbrace{\hat{\theta}}^{m}$ & $\begin{array}{l}\infty \\
\infty \\
\infty \\
\infty\end{array}$ & n & ڤֶ. & 8 & $\tilde{\tilde{\sigma}}$ & $\begin{array}{l}\infty \\
\infty \\
\infty \\
\infty\end{array}$ & $\begin{array}{l}0 \\
\infty \\
\infty \\
n \\
n\end{array}$ & $\stackrel{m}{m}$ & ৪ \\
\hline 它 E & ๙̃. & Е. & $\hat{\dot{q}}$ & à & \begin{tabular}{|l}
$\infty$ \\
$\stackrel{\infty}{\sigma}$ \\
$\dot{\sigma}$
\end{tabular} & 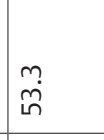 & 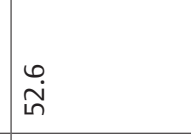 & 谒 & $\stackrel{m}{i}$ & q & बू \\
\hline 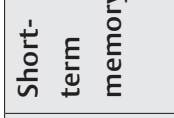 & 㐫. & $\stackrel{\infty}{\dot{\sigma}}$ & à & б & $\begin{array}{l}0 \\
\dot{\sigma} \\
\end{array}$ & $\begin{array}{l}m \\
\tilde{n}\end{array}$ & $\begin{array}{l}0 \\
\text { ڤં }\end{array}$ & જે & $\stackrel{m}{n}$ & 苞 & 8 \\
\hline 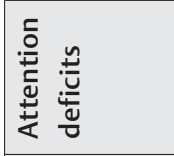 & 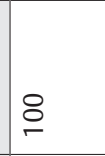 & Na & $\hat{\tilde{a}}$ & 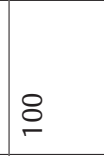 & $\mid \begin{array}{l}\infty \\
\infty \\
\infty \\
\infty\end{array}$ & 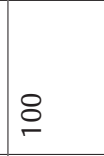 & $\hat{\sigma}$ & $\stackrel{8}{-}$ & $\stackrel{8}{\circ}$ & $\begin{array}{l}\infty \\
\dot{a} \\
a\end{array}$ & นn \\
\hline 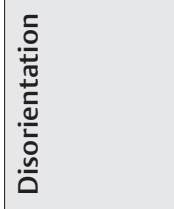 & $\nsubseteq$ & 苞 & $\stackrel{8}{\circ}$ & $\nsubseteq$ & $\begin{array}{l}\infty \\
\infty \\
\infty \\
\infty\end{array}$ & 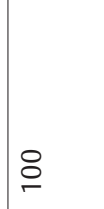 & $\mid \begin{array}{l}\infty \\
\infty \\
\infty\end{array}$ & $\bar{g}$ & $\frac{m}{\infty}$ & 吕 & 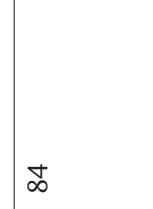 \\
\hline 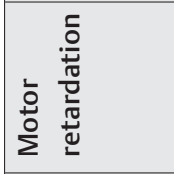 & ब্ं & $\overline{\dot{m}}$ & $\stackrel{+}{\stackrel{m}{m}}$ & $a$ & nُ & $\stackrel{m}{m}$ & 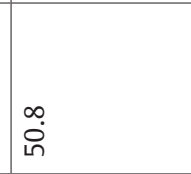 & $\stackrel{\sim}{\sim}$ & $\overbrace{n}^{m}$ & 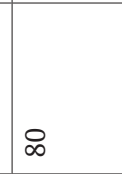 & $\stackrel{\infty}{\llcorner}$ \\
\hline 吾 & ठ & 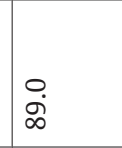 & 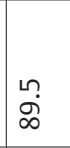 & क & $\mid \begin{array}{l}9 \\
\infty \\
\infty\end{array}$ & $\tilde{m}$ & $\stackrel{m}{a}_{a}$ & 卢 & 导 & $\stackrel{m}{n}$ & 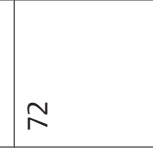 \\
\hline 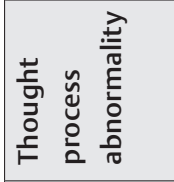 & ڤn & 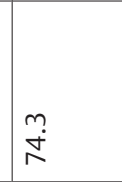 & $\begin{array}{l}\text { Ln } \\
\infty \\
\infty\end{array}$ & $\tilde{\sigma}$ & $\stackrel{N}{N}$ & $\stackrel{m}{n}$ & f & $\infty$ & 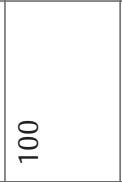 & $\aleph_{n}^{m}$ & $\widetilde{6}$ \\
\hline 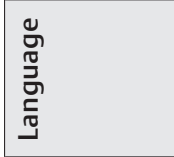 & 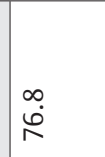 & 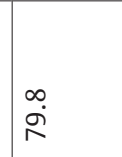 & $\stackrel{m}{i}$ & 8 & 文 & $\stackrel{m}{i}$ & 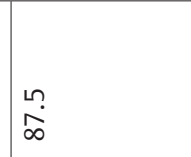 & $\stackrel{\hat{\infty}}{\stackrel{\infty}{\infty}}$ & 苟 & $\stackrel{\widetilde{Y}}{\forall}$ & $\mathscr{f}$ \\
\hline 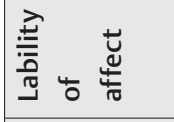 & $\stackrel{\stackrel{n}{R}}{\stackrel{1}{R}}$ & ָ̇ & mi & d & む & 8 & 岁 & $\infty$ & $m_{i}^{m}$ & 竎 & 6 \\
\hline 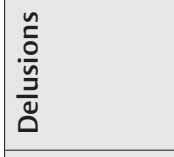 & $\begin{array}{l}\infty \\
\stackrel{\infty}{\sim}\end{array}$ & $\begin{array}{l}\stackrel{\infty}{\infty} \\
\stackrel{m}{m}\end{array}$ & $\stackrel{\substack{n \\
m}}{\stackrel{m}{n}}$ & \pm & î & $\stackrel{m}{m}$ & 苟 & 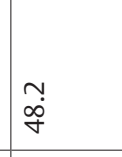 & 0 & 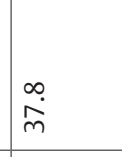 & $\hat{6}$ \\
\hline 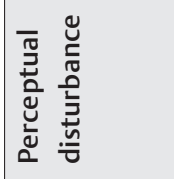 & ڤ̃ & 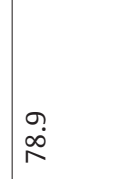 & $\stackrel{\hat{j}}{\grave{L}}$ & $\stackrel{m}{m}$ & 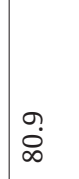 & $\infty$ & 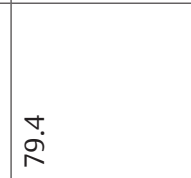 & ก & nુ & $\begin{array}{l}\stackrel{a}{o} \\
\dot{\rho}\end{array}$ & I \\
\hline 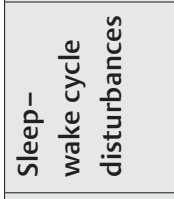 & 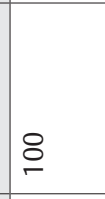 & $\stackrel{n}{a}$ & $\stackrel{\circ}{\circ}$ & g & 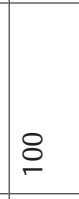 & $\hat{\phi}$ & $\infty$ & 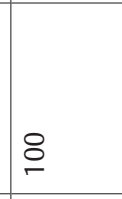 & fo & 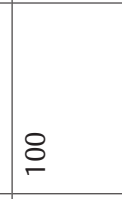 & $\tilde{\sigma}$ \\
\hline 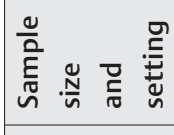 & is & gi & $\begin{array}{l}0 \\
\mathcal{Z} \\
\infty \\
\infty\end{array}$ & छ் & \begin{tabular}{|l} 
E \\
$\dot{D}$ \\
$\dot{\infty}$ \\
\end{tabular} & $\begin{array}{l}0 \\
3 \\
i\end{array}$ & 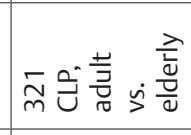 & 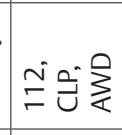 & $n \cdot \frac{\partial}{\alpha}$ & $\frac{3}{0}$ & 过 \\
\hline 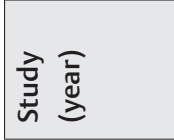 & 产 & 产 & 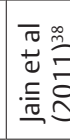 & 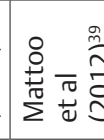 & 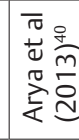 & 产离 & 离 & 这离 & 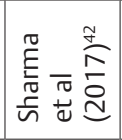 & 离产 & 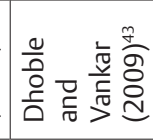 \\
\hline
\end{tabular}


Delirium Research in India Grover et al. 243

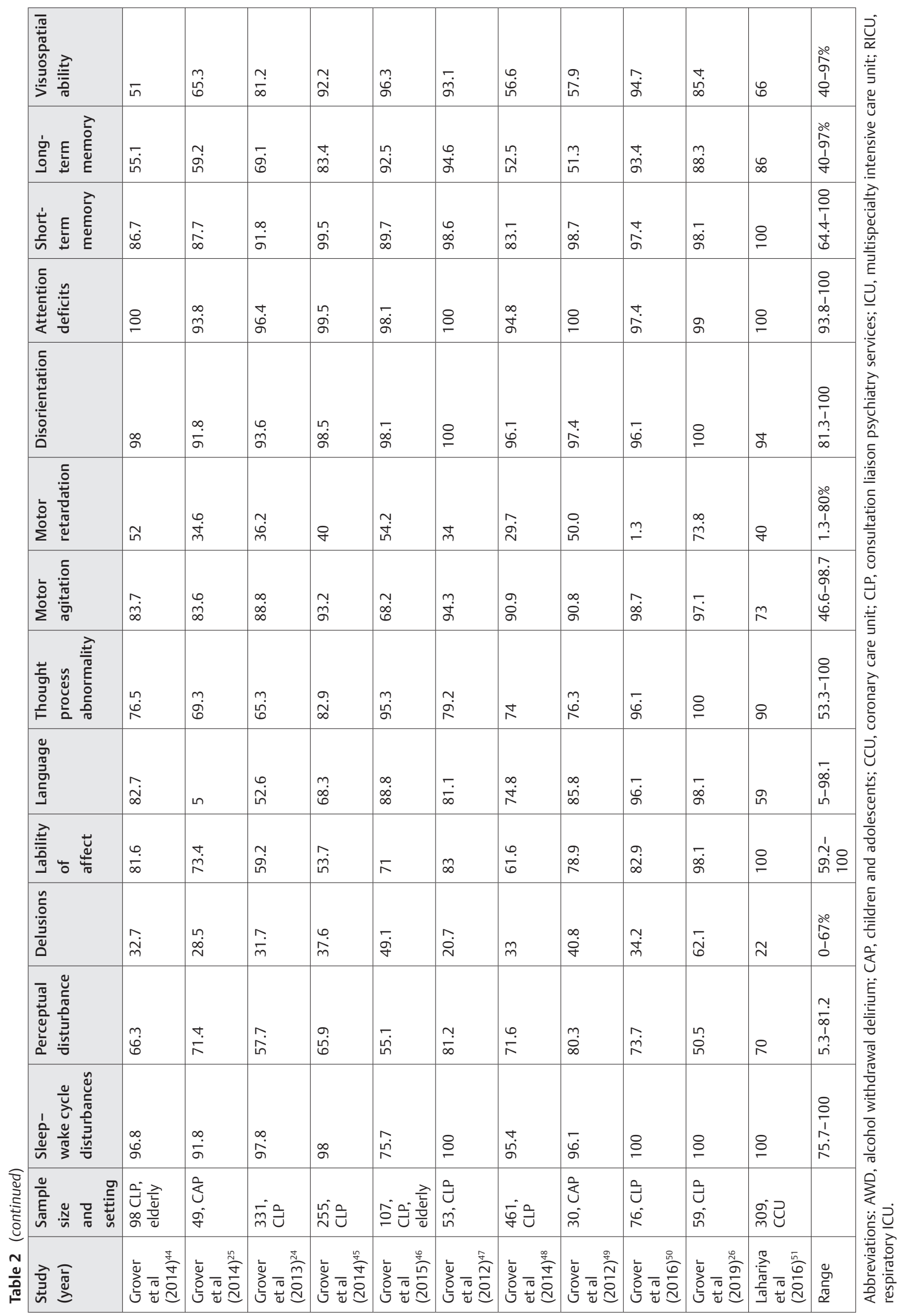

Journal of Neurosciences in Rural Practice Vol. 12 No. 2/2021 $\quad$ @ 2021. Association for Helping Neurosurgical Sick People. 
Table 3 Factor analytic studies of delirium from India

\begin{tabular}{|c|c|c|c|c|c|}
\hline Study (year) & $\begin{array}{l}\text { Sample } \\
\text { size }\end{array}$ & \begin{tabular}{|l|} 
Treatment \\
setting
\end{tabular} & Scales used & $\begin{array}{l}\text { Percentage } \\
\text { of variance } \\
\text { explained } \\
(\%)\end{array}$ & Factor structure \\
\hline $\begin{array}{l}\text { Shyamsundar } \\
\text { et al }(2009)^{22}\end{array}$ & 120 & ICU & MDAS & 62.7 & $\begin{array}{l}\text { Factor I (“cognitive disturbance”): impaired digit span, short-term memory } \\
\text { impairment, disorientation, and inattention } \\
\text { Factor II (“behavioral abnormality”): altered psychomotor activity, per- } \\
\text { ceptual disturbances, delusions, disorganized thinking, sleep-wake cycle } \\
\text { disturbances, and reduced awareness }\end{array}$ \\
\hline $\begin{array}{l}\text { George et al } \\
(2011)^{52}\end{array}$ & 53 & ICU & ICDSC & 56.2 & $\begin{array}{l}\text { Factor-I (altered sensorium/psychopathology): altered level of conscious- } \\
\text { ness, inattention, disorientation, hallucination/delusion/psychosis, psycho- } \\
\text { motor agitation, and inappropriate speech or mood } \\
\text { Factor-II (sleep-wake cycle problems): sleep-wake cycle disturbances and } \\
\text { fluctuation of symptoms }\end{array}$ \\
\hline $\begin{array}{l}\text { Jain et al } \\
(2011)^{38}\end{array}$ & 86 & CLP & $\begin{array}{l}\text { DRS-R-98 } \\
\text { separately } \\
\text { and DRS-R- } \\
\text { 98, MDAS, } \\
\text { and CSE } \\
\text { combined }\end{array}$ & 47.8 & $\begin{array}{l}\text { Factor I ("cognitive"): abnormalities of language, thought process, } \\
\text { orientation, attention, short-term memory, long-term memory, visuospa- } \\
\text { tial ability, reduced level of consciousness (awareness), and perseveration } \\
\text { or prolonged latency } \\
\text { Factor II ("behavioral”): sleep-wake cycle disturbances, delusions, per- } \\
\text { ceptual disturbances including hallucinations, motor agitation, inverse of } \\
\text { motor retardation, lability of affect, distractibility, irritability, and temporal } \\
\text { onset of symptoms }\end{array}$ \\
\hline $\begin{array}{l}\text { Grover et al } \\
(2011)^{37}\end{array}$ & 151 & $\begin{array}{l}\text { CLP, drug } \\
\text { naive }\end{array}$ & DRS-R-98 & 47.32 & $\begin{array}{l}\text { Factor I (cognitive): attention, orientation, short-term memory, long-term } \\
\text { memory, and visuospatial ability } \\
\text { Factor II (sleep and motoric disturbances): sleep-wake cycle disturbances, } \\
\text { delusions, perceptual disturbances, lability of affect, motor agitation, and } \\
\text { inverse of motor retardation } \\
\text { Factor III (thought, language, and fluctuations): language, thought process } \\
\text { abnormality, temporal onset of symptoms, and fluctuations }\end{array}$ \\
\hline $\begin{array}{l}\text { Grover et al } \\
(2012)^{28}\end{array}$ & 109 & CLP, elderly & DRS-R-98 & 43.5 & $\begin{array}{l}\text { Factor I (cognitive): thought disturbance, short-term memory, long-term } \\
\text { memory, and visuospatial disturbance } \\
\text { Factor II (cognitive and diagnostic factor): disturbance of attention and } \\
\text { concentration and the three items of diagnostic significance (temporal } \\
\text { onset, fluctuation, and presence of physical disorder) } \\
\text { Factor III (psychotic and motoric symptoms): perceptual disturbances, } \\
\text { delusions, and the motoric disturbances }\end{array}$ \\
\hline $\begin{array}{l}\text { Mattoo et al } \\
(2012)^{39}\end{array}$ & 100 & $\begin{array}{l}\text { CLP, mixed } \\
\text { adult and } \\
\text { elderly }\end{array}$ & DRS-R-98 & $\begin{array}{l}48.5 \\
59\end{array}$ & $\begin{array}{l}\text { 2-factor model } \\
\text { Factor I (cognition and thinking): delusions, language disturbances, } \\
\text { thought process abnormality, attention, orientation, short-term memory, } \\
\text { long-term memory, visuospatial ability, and temporal onset of symptoms } \\
\text { Factor I (circadian): motoric disturbances and fluctuations } \\
\text { 3-factor model } \\
\text { Factor I (cognition): attention, orientation, short-term memory, long-term } \\
\text { memory, visuospatial ability, and fluctuation } \\
\text { Factor II (circadian and psychosis): sleep disturbances, delusions, hallucina- } \\
\text { tions, and motoric disturbances } \\
\text { Factor III (higher order thinking): language disturbances, thought process } \\
\text { abnormality, and temporal onset of symptoms }\end{array}$ \\
\hline $\begin{array}{l}\text { Grover et al } \\
(2013)^{41}\end{array}$ & 321 & $\begin{array}{l}\text { CLP, mixed } \\
\text { adult and } \\
\text { elderly }\end{array}$ & DRS-R-98 & 45.8 & $\begin{array}{l}\text { Factor I (psychotic and motoric disturbances): sleep-wake cycle dis- } \\
\text { turbances, delusions, perceptual disturbances, lability of affect, motor } \\
\text { agitation, inverse of motor retardation, and fluctuation } \\
\text { Factor II (cognitive): language, thought process abnormality, short-term } \\
\text { memory, long-term memory, and visuospatial ability } \\
\text { Factor III (diagnostic factor): attention, orientation, temporal onset of } \\
\text { symptoms, and physical disorder }\end{array}$ \\
\hline $\begin{array}{l}\text { Grover et al } \\
(2013)^{41}\end{array}$ & 245 & CLP, adult & DRS-R-98 & 46.75 & $\begin{array}{l}\text { Factor I (psychotic and motoric disturbances): sleep-wake cycle dis- } \\
\text { turbances, delusions, perceptual disturbances, lability of affect, motor } \\
\text { agitation, inverse of motor retardation, and fluctuation } \\
\text { Factor II (cognitive): language, thought process abnormality, short-term } \\
\text { memory, long-term memory, and visuospatial ability } \\
\text { Factor III (diagnostic factor): attention, orientation, temporal onset of } \\
\text { symptoms, and physical disorder }\end{array}$ \\
\hline
\end{tabular}


Table 3 (continued)

\begin{tabular}{|c|c|c|c|c|c|}
\hline Study (year) & $\begin{array}{l}\text { Sample } \\
\text { size }\end{array}$ & \begin{tabular}{|l|} 
Treatment \\
setting
\end{tabular} & Scales used & $\begin{array}{l}\text { Percentage } \\
\text { of variance } \\
\text { explained } \\
(\%)\end{array}$ & Factor structure \\
\hline $\begin{array}{l}\text { Grover et al } \\
(2013)^{41}\end{array}$ & 76 & CLP, elderly & DRS-R-98 & 48.53 & $\begin{array}{l}\text { Factor I (cognitive-1): delusions, language disturbance, thought process } \\
\text { abnormality, long-term memory, and visuospatial ability } \\
\text { Factor II (psychotic and motoric disturbances): sleep-wake cycle dis- } \\
\text { turbances, perceptual disturbances, motor agitation, inverse of motor } \\
\text { retardation, fluctuation, and physical disorder } \\
\text { Factor III (cognitive-2): inverse of lability of affect, attention, orientation, } \\
\text { short term memory, and temporal onset of symptoms }\end{array}$ \\
\hline $\begin{array}{l}\text { Sharma et al } \\
(2017)^{42}\end{array}$ & 75 & RICU & DRS-R-98 & $54.6-63.4$ & $\begin{array}{l}\text { Factor I (cognitive factor): attention, orientation, short term memory, } \\
\text { long-term memory, and visuospatial ability } \\
\text { Factor II (motoric disturbances): motor agitation, inverse of motor retarda- } \\
\text { tion, and lability of affect } \\
\text { Factor III (behavioral disturbances): language disturbance, thought process } \\
\text { abnormality, temporal onset of symptoms, fluctuation }\end{array}$ \\
\hline $\begin{array}{l}\text { Grover et al } \\
(2018)^{15}\end{array}$ & 66 & ICU & $\begin{array}{l}\text { DRS-R-98 } \\
\text { and MDAS }\end{array}$ & 56.3 & $\begin{array}{l}\text { Factor I: perceptual disturbance, delusion, lability of affect, language, } \\
\text { thought process abnormality, orientation, short-term memory, long-term } \\
\text { memory, visuospatial ability, and impaired digit span } \\
\text { Factor II: motor agitation and inverse of motor retardation } \\
\text { Factor III: sleep wake cycle disturbances, reduced level of consciousness, } \\
\text { and reduced ability to maintain and shift attention }\end{array}$ \\
\hline $\begin{array}{l}\text { Grover et al } \\
(2016)^{31}\end{array}$ & 112 & CLP, AWD & DRS-R98 & 50.09-56.59 & $\begin{array}{l}\text { Whole sample } \\
\text { Factor I (cognitive factor): attention, orientation, short-term memory, } \\
\text { long-term memory, visuospatial ability, language, and thought process } \\
\text { abnormality } \\
\text { Factor II (psychotic): perceptual disturbance, delusion, fluctuation of symp- } \\
\text { toms, and presence of physical disorder } \\
\text { Factor III (motoric-circadian disturbance): sleep-wake cycle disturbance, } \\
\text { lability of affect, motor agitation, and inverse of motor retardation } \\
\text { Pure AWD } \\
\text { Factor I (psychotic): perceptual disturbance, delusion, language, thought } \\
\text { process abnormality, lability of affect, long-term memory, and visuospatial } \\
\text { ability } \\
\text { Factor II (cognitive factor): attention, orientation, short-term memory, and } \\
\text { physical disorder } \\
\text { Factor III (motoric-circadian disturbance): sleep-wake cycle distur- } \\
\text { bance, motor agitation, inverse of motor retardation, and fluctuation of } \\
\text { symptoms } \\
\text { AWD with associated etiologies } \\
\text { Factor I (psychotic): perceptual disturbance, delusion, fluctuation of symp- } \\
\text { toms, and presence of physical disorder } \\
\text { Factor II (cognitive factor): attention, orientation, short term memory, } \\
\text { physical disorder, language, thought process abnormality, long-term } \\
\text { memory, visuospatial ability, and acute onset of symptoms } \\
\text { Factor III (motoric-circadian disturbance): sleep-wake cycle disturbance, } \\
\text { lability of affect, motor agitation, and inverse of motor retardation }\end{array}$ \\
\hline
\end{tabular}

Abbreviations: AWD, alcohol withdrawal delirium; CLP, consultation liaison psychiatry services; CSE, confusional state evaluation; DRS, delirium rating scale; DRS-R-98, DSR revised-1998; ICDSC, intensive care delirium screening checklist; ICU, intensive care unit; MDAS, memorial delirium assessment scale; RICU, RICU, respiratory ICU.

included the opinion of clinicians from India too, although did not provide India specific data, suggests that in Asia, 80\% of the clinicians implement delirium monitoring, with CAMICU being the most common scale for assessment. ${ }^{70}$ However, in terms of the prevalence of delirium, again the awareness was low, with only $2 \%$ of the clinicians from Asia believed that $>60 \%$ of the patients in the ICU have delirium. One of the studies specifically focused on nurses. ${ }^{71}$ In this study, the authors assessed the knowledge of the nurses before an education program for delirium and showed that providing knowledge about delirium to the nurses was associated with significant improvement in the knowledge and practice of nurses toward delirium.

\section{Studies Focusing on the Experience of Patients with Delirium}

Three studies (-Table 5) $)^{26,53,72}$ have evaluated the patients' experience and distress after the resolution of symptoms of delirium. These studies suggest that about one-fourth $(28.3 \%)^{72}$ to one-third $(35 \%)^{53}$ of patients remember their experience of delirium. Those who could remember their experience reported moderate-to-severe levels of distress. Those who remembered their experience, in general, 
Table 4 Prevalence of motoric subtypes in different studies

\begin{tabular}{|c|c|c|c|c|c|c|c|c|}
\hline Study (year) & $\begin{array}{l}\text { Treatment } \\
\text { setting }\end{array}$ & $\begin{array}{l}\text { Diagnostic } \\
\text { system used }\end{array}$ & $\begin{array}{l}\text { Sample } \\
\text { size }\end{array}$ & $\begin{array}{l}\text { Assessment } \\
\text { of motoric } \\
\text { subtype }\end{array}$ & $\begin{array}{l}\text { Hypoactive } \\
\text { (\%) }\end{array}$ & $\begin{array}{l}\text { Mixed } \\
(\%)\end{array}$ & $\begin{array}{l}\text { Hyperactive } \\
\text { (\%) }\end{array}$ & $\begin{array}{l}\text { No subtype } \\
\text { (\%) }\end{array}$ \\
\hline $\begin{array}{l}\text { Grover et al } \\
(2014)^{25}\end{array}$ & CLP & DSM-IV TR & 98 & DMSS & 23.5 & 21.4 & 45.9 & 8.2 \\
\hline $\begin{array}{l}\text { Grover and } \\
\text { Shah }(2012)^{47}\end{array}$ & CLP & DSM-IV & 53 & DMSS & 17 & 18.9 & 58.5 & 5.6 \\
\hline $\begin{array}{l}\text { Grover et al } \\
(2014)^{44}\end{array}$ & CLP, CAP & DSM-IV TR & 49 & DMSS & 16.3 & 26.5 & 53 & 4 \\
\hline $\begin{array}{l}\text { Grover et al } \\
(2018)^{15}\end{array}$ & ICU & DSM-IV TR & 66 & DMSS & 47 & 29 & 24.5 & - \\
\hline $\begin{array}{l}\text { Jayaswal et al } \\
(2019)^{18}\end{array}$ & Medical ICU & CAM-ICU & 280 & RASS & 55.7 & 10.2 & 34.1 & - \\
\hline $\begin{array}{l}\text { Barman et al } \\
(2018)^{23}\end{array}$ & $\begin{array}{l}\text { Multidisciplinary } \\
\text { ICU }\end{array}$ & DSM-IV & 310 & RASS & 65 & 19.3 & $15.7 \%$ & - \\
\hline $\begin{array}{l}\text { Lahariya et al } \\
(2016)^{51}\end{array}$ & $\mathrm{CCU}$ & DSM-IV TR & 309 & Amended DMSS & 26 & 11.1 & 56.8 & 5 \\
\hline $\begin{array}{l}\text { Grover et al } \\
(2015)^{53}\end{array}$ & CLP & DSM-IV TR & 203 & Amended DMSS & 7.3 & 36.1 & 56.6 & - \\
\hline $\begin{array}{l}\text { Grover et al } \\
(2014)^{29}\end{array}$ & CLP & DSM-IV TR & 321 & Amended DMSS & 19.93 & 24.61 & 50.15 & 5.29 \\
\hline $\begin{array}{l}\text { Jain et al } \\
(2011)^{38}\end{array}$ & CLP & DSM-IV TR & 86 & DRS-R-98 & 10 & 21 & 69 & - \\
\hline $\begin{array}{l}\text { Kumar et al } \\
(2015)^{54}\end{array}$ & General hospital & DSM-IV TR & 80 & MDAS & 30 & 0 & 70 & - \\
\hline $\begin{array}{l}\text { Khurana et al } \\
(2011)^{14}\end{array}$ & Inpatient elderly & CAM & 400 & $\begin{array}{l}\text { Self-designed } \\
\text { criteria }\end{array}$ & 65 & 10 & 25 & - \\
\hline $\begin{array}{l}\text { Mushtaq et al } \\
(2014)^{55}\end{array}$ & $\begin{array}{l}\text { Medical-surgical } \\
\text { wards }\end{array}$ & DSM-IV TR & 80 & $\begin{array}{l}\text { Self-designed } \\
\text { criteria }\end{array}$ & 30 & 0 & 70 & - \\
\hline
\end{tabular}

Abbreviations: CAM-ICU, confusion assessment method for the intensive care unit; CAP, children and adolescents; CCU, coronary care unit; CLP, consultation liaison psychiatry; DMSS, delirium motor subtyping scale; DRS-R-98, delirium rating scale revised-1998; DSM IV TR, diagnostic and statistical manual of mental disorders, fourth edition, text revision; ICU, intensive care unit; MDAS, memorial delirium assessment scale; RASS, Richmond agitation-sedation scale.

described it as a state of fearfulness, anxiety, confusion, and feeling strange. ${ }^{72}$ One of the studies reported that the most common distressing themes which were recollected were fear and visual hallucination. ${ }^{53}$ In terms of symptom profile, recall of delirium experience was associated with a higher prevalence of perceptual and language disturbances, and a higher severity of delirium. Those who could not remember their delirium experience also were distressed and more often reported moderate-to-severe distress. One of the studies evaluated the patient experience in terms of posttraumatic stress disorder (PTSD) and reported that $30.5 \%$ of the patients had substantial symptoms of PTSD, 22\% ( $n=13)$ had probable symptoms of PTSD, and $15.3 \%$ were considered to have partial symptoms of PTSD after the resolution of delirium. Again, the experience of PTSD was associated with higher severity of delirium and in terms of specific symptoms, it was associated with higher mean scores for the items of motor agitation and attentional deficits. ${ }^{26}$

\section{Studies Focusing on Caregivers of Patients with Delirium}

Two studies have focused on family caregivers. ${ }^{47,73}$ According to one of the studies, symptoms of delirium are attributed to the nonorganic causes by about one-third of the caregivers. ${ }^{47}$ Other paper based on the same cohort reported severe or very severe distress in about two-thirds of the caregivers. ${ }^{73}$

\section{Effectiveness of Medications in the Treatment of Delirium}

Few studies ( - Table $\mathbf{6})^{74-78}$ have evaluated the effectiveness of various antipsychotic medications in the management of delirium in CLP setting. ${ }^{74-77}$ Three of these studies ${ }^{74-76}$ suggest that the atypical antipsychotics like olanzapine, risperidone, and quetiapine are equally effective as haloperidol. One retrospective study also showed the effectiveness of risperidone. ${ }^{77}$ One double-blind randomized controlled trial (DBRCT) compared the beneficial effect of melatonin with placebo in patients admitted to ICU with organophosphorus poisoning. ${ }^{78}$ This study showed that the use of melatonin is associated with a lower prevalence of delirium after 3 days and patients receiving melatonin spend lower time in delirium when compared with a placebo group.

\section{Prevention of Postoperative Emergence Delirium}

It is well known that the use of flurane in anesthesia among children and adolescents is associated with a 
Table 5 Findings reported in different studies done in different treatment settings

\begin{tabular}{|c|c|c|}
\hline Study (year) & Setting & Findings \\
\hline \multicolumn{3}{|c|}{ Studies focusing on ICU patients } \\
\hline $\begin{array}{l}\text { Grover et al } \\
(2017)^{56}\end{array}$ & $\begin{array}{l}\text { ICU } \\
n=66 \text { (prospective } \\
\text { arm) }\end{array}$ & $\begin{array}{l}\text { - Wide gap in the actual incidence and prevalence of delirium in ICU patients and those } \\
\text { referred to psychiatry consultation liaison services }\end{array}$ \\
\hline $\begin{array}{l}\text { Mohan et al } \\
(2015)^{57}\end{array}$ & $\begin{array}{l}\text { Neuro ICU } \\
30 \text { patients divided } \\
\text { into two groups }\end{array}$ & $\begin{array}{l}\text { - Compared the severity of symptoms of delirium, as assessed by DRS-R-98, between } \\
\text { patients with and without MRI changes } \\
\text { - Those with neuroimaging changes had lower severity of delirium, compared with } \\
\text { those without neuroimaging changes }\end{array}$ \\
\hline $\begin{array}{l}\text { Jayaswal et al } \\
(2019)^{18}\end{array}$ & $\begin{array}{l}\text { Medical ICU } \\
n=280\end{array}$ & $\begin{array}{l}\text { - Factors, which significantly predispose the persons to develop delirium include } \\
\text { tobacco use, chronic liver disease, and past episodes of delirium } \\
\text { - Factors which significantly precipitate delirium include mechanical ventilation, } \\
\text { hypoxia, fever, raised levels of bilirubin and creatinine, and use of benzodiazepines } \\
\text { - Delirium was significantly associated with longer ICU stay and 1-month postdischarge } \\
\text { mortality }\end{array}$ \\
\hline $\begin{array}{l}\text { George et al } \\
(2011)^{52}\end{array}$ & $\begin{array}{l}\text { Medical ICU } \\
n=59\end{array}$ & $\begin{array}{l}\text { - A score of } 3 \text { or more on ICDSC, is an indicator of delirium } \\
\text { - When the original cut-off of } 4 \text { was used, sensitivity and specificity were } 75 \% \text { and } 74 \% \text {, } \\
\text { respectively; but a cut-off of } 3 \text { led to increase in sensitivity to } 90 \% \text {, but the specificity } \\
\text { of } 61.54 \% \\
\text { - The ICDSC had good internal consistency, with Cronbacha of } 0.754 \\
\text { - The ICDSC had good internal consistency, with Cronbacha } \\
\text { - The ICDSC had good internal consistency, with Cronbach } \alpha \text { of } 0.754\end{array}$ \\
\hline $\begin{array}{l}\text { Sharma et al } \\
(2012)^{19}\end{array}$ & $\begin{array}{l}\mathrm{RICU} \\
n=140\end{array}$ & $\begin{array}{l}\text { - Predisposing factors identified in univariate analysis: higher age, higher Glasgow } \\
\text { coma scale score, increased APACHE II score, hyperuricemia, hypoalbuminemia, pres- } \\
\text { ence of acidosis, abnormal alkaline transferase levels, use of mechanical ventilation, } \\
\text { higher number of total medication received and use of sedative, steroids and insulin } \\
\text { - Compared with those without delirium, patients with delirium had significantly lon- } \\
\text { ger duration of ICU stay and higher mortality rates } \\
\text { - Risk factors associated with mortality in patients with delirium: Age, multiple organ } \\
\text { failure, hypoactive delirium and higher DRS-R-98 scores }\end{array}$ \\
\hline $\begin{array}{l}\text { Barman et al } \\
(2018)^{23}\end{array}$ & $\begin{array}{l}\mathrm{ICU} \\
n=310\end{array}$ & $\begin{array}{l}\text { - Evaluated the diagnostic accuracy of CAM-ICU and ICDSC } \\
\text { - The inter rater agreement (kappa coefficient) between nurse and intensivist was } 0.86 \\
\text { ( } 95 \% \mathrm{Cl}: 0.8-0.9) \text { and } 0.89(95 \% \mathrm{Cl}: 0.83-0.96) \text { for CAM-ICU and ICDSC respectively } \\
\text { - Overall sensitivity and specificity were } 84.4 \%(95 \% \mathrm{Cl}: 70.5-93.5 \%) \text { and } 94.6 \%(95 \% \\
\mathrm{CI}: 84.9-98.9 \%) \text { for CAM-ICU, } 77.8 \%(95 \% \mathrm{Cl}: 62.9-88.8 \%) \text { and } 94.6 \%(95 \% \mathrm{Cl}: 84.9- \\
98.9 \%) \text { for ICDSC. } \\
\text { - CAM-ICU has higher sensitivity and diagnostic odds ratio }(84 \%, 86.1) \text { compared with } \\
\text { ICDSC }\end{array}$ \\
\hline
\end{tabular}

higher rate of emergent delirium and agitation. Given the same, many studies ( - Table 7$)^{79-91}$ have evaluated the beneficial effects of additional use of agents, like ketamine (low and high doses), ${ }^{79}$ midazolam, ${ }^{80,82,83,85}$ dexmedetomidine, ${ }^{81-83,86,87,89,90}$ propofol, $^{81}$ glycopyrrolate, ${ }^{82}$ and bupivacaine ${ }^{84}$ in reducing the incidence of delirium. Some of the studies have also evaluated different doses of the same medications, ${ }^{79,87}$ whereas others have evaluated the different techniques of administration of these drugs ${ }^{86}$ and some of the studies have evaluated the different timing of giving these medications. ${ }^{80}$ In general, available data suggest that the incidence of emergent delirium is lower with dexmedetomidine when compared with other agents (ketamine, midazolam, and clonidine) and placebo. ${ }^{81-83,86,87,89,90}$ Compared with the use of bupivacaine only, the use of adjuvant ketamine along with bupivacaine is protective against emergence delirium in children. ${ }^{84}$ It has 
Table 5 (continued)

\begin{tabular}{|c|c|c|}
\hline Study (year) & Setting & Findings \\
\hline $\begin{array}{l}\text { Lahariya et al } \\
(2014)^{20}\end{array}$ & $\begin{array}{l}\text { CCU } \\
n=309\end{array}$ & $\begin{array}{l}\text { - Risk factors for delirium, identified in binary logistic regression analysis: hypokalemia, } \\
\text { Sequential organ failure assessment score, presence of cognitive deficits, receiving } \\
\text { more than three medications, sepsis, hyponatremia, presence of cardiogenic shock, } \\
\text { having undergone coronary artery bypass grafting, left ventricular ejection fraction } \\
<30 \text {, currently receiving opioids, age more than } 65 \text { years, presence of diabetes melli- } \\
\text { tus, presence of uncontrolled diabetes mellitus, history of seizures, presence of con- } \\
\text { gestive cardiac failure, having undergone angioplasty, presence of atrial fibrillation, } \\
\text { ongoing depression, currently receiving/taking benzodiazepines, warfarin, ranitidine, } \\
\text { steroids, nonsteroidal anti-inflammatory drugs, higher total number of medications, } \\
\text { presence of raised creatinine, anemia, hypoglycemia, acute physiology, and chronic } \\
\text { health evaluation II score and Charlson's comorbidity index score } \\
\text { - Mortality rate (27\%) was significantly higher among those with delirium, compared } \\
\text { with those without delirium (1\%) } \\
\text { - The duration of ICU stay was significantly longer for those with delirium, compared } \\
\text { with those who did not develop delirium } \\
\text { - Risk factors for mortality among patient with delirium: uncontrolled diabetes melli- } \\
\text { tus, cardiogenic shock, sepsis, presence of diabetes mellitus, higher APACHE-II score, } \\
\text { higher SOFA score, and higher Charlson's score }\end{array}$ \\
\hline $\begin{array}{l}\text { Shyamsundar } \\
\text { et al }(2009)^{22}\end{array}$ & $\begin{array}{l}\text { Medical and cardiac } \\
\text { ICU } \\
n=120\end{array}$ & $\begin{array}{l}\text { - Validation of memorial delirium rating scale (MDAS) } \\
\text { - The scale has good interrater agreement (0.92; 95\% confidence interval,0.81-0.96) } \\
\text { and test-retest reliability (0.93; 95\% Cl: 0.83-0.97) } \\
\text { - The MDAS had good internal consistency (Cronbacha: } 0.89) \\
\text { - The MDAS had good internal consistency (Cronbacha } \\
\text { - The MDAS had good internal consistency (Cronbacha: } 0.89) \\
\text { - A ROC showed that the optimal threshold for screening as MDAS total score of at } \\
\text { least } 10 \\
\text { - This cut-off has high sensitivity ( } 100 \%), \text { specificity ( } 95.45 \%), \text { positive predictive value } \\
\text { (75\%), and negative predictive value (100\%) }\end{array}$ \\
\hline \multicolumn{3}{|c|}{ Alcohol withdrawal delirium } \\
\hline $\begin{array}{l}\text { Sarkar et al } \\
(2017)^{58}\end{array}$ & $\begin{array}{l}\text { Psychiatry setting } \\
n=80\end{array}$ & $\begin{array}{l}\text { - Factors associated with development of alcohol withdrawal delirium include: Heavy } \\
\text { drinking, continuous pattern of drinking, past history of delirium, alcohol induced } \\
\text { psychosis, and presence of cognitive deficits }\end{array}$ \\
\hline $\begin{array}{l}\text { Baby et al } \\
(2017)^{59}\end{array}$ & $\begin{array}{l}\text { Emergency and } \\
\text { inpatient services } \\
\text { Emergency }(n=111) \\
\text { Comprehensive } \\
\text { inpatient addiction } \\
\text { treatment (CIAT) } \\
(n=107)\end{array}$ & $\begin{array}{l}\text { - Patients who received both emergency and comprehensive inpatient addiction treat- } \\
\text { ment had better regular follow-up compared with patients treated in the emergency } \\
\text { services alone at } 6 \text { months } \\
\text { - Comprehensive inpatient addiction treatment also resulted in better combined fol- } \\
\text { low-up (regular follow-up and telephonic follow-up) } \\
\text { - Compared with emergency services treatment group alone, emergency services plus } \\
\text { comprehensive inpatient addiction treatment group had fewer relapses }\end{array}$ \\
\hline $\begin{array}{l}\text { Grover et al } \\
(2016)^{31}\end{array}$ & $n=112$, AWD & - Factor structure of pure AWD is different from AWD with associated etiologies \\
\hline $\begin{array}{l}\text { Grover et al } \\
(2013)^{30}\end{array}$ & $\begin{array}{l}\text { CLP } \\
n=112, \text { AWD }\end{array}$ & $\begin{array}{l}\text { - Compared with those with delirium due to medical-surgical causes, patients with delir- } \\
\text { ium associated with alcohol withdrawal more often have delusions and thought process } \\
\text { abnormality; and less often have motor retardation, long term memory deficits, and } \\
\text { visuospatial ability }\end{array}$ \\
\hline $\begin{array}{l}\text { Malhotra et al } \\
(2018)^{60}\end{array}$ & $\begin{array}{l}n=210 \text { patients with } \\
\text { alcohol dependence } \\
\text { and } 200 \text { controls }\end{array}$ & $\begin{array}{l}\text { - Delirium tremens was significantly associated with T allele carrying status (GT and TT } \\
\text { [rs1824024]) of muscarinic cholinergic receptor } 2 \text { (CHRM2) }\end{array}$ \\
\hline
\end{tabular}


Table 5 (continued)

\begin{tabular}{|c|c|c|}
\hline Study (year) & Setting & Findings \\
\hline \multicolumn{3}{|l|}{ CLP setting } \\
\hline $\begin{array}{l}\text { Prinka and } \\
\text { Sharma }(2016)^{61}\end{array}$ & $\begin{array}{l}\text { Emergency and CLP } \\
n=100\end{array}$ & $\begin{array}{l}\text { - Compared clinical profile of patients of delirium seen in emergency and CLP set-up- } \\
\text { Subtle differences noted between the two groups }\end{array}$ \\
\hline $\begin{array}{l}\text { Grover et al } \\
(2017)^{62}\end{array}$ & $\begin{array}{l}\text { CLP } \\
n=219\end{array}$ & $\begin{array}{l}\text { - Delirium is the most common diagnosis made by the CLP team } \\
\text { - Diagnostic concordance between the diagnosis of delirium made by the psychiatrist } \\
\text { and that made by the physicians/surgeons is low }\end{array}$ \\
\hline $\begin{array}{l}\text { Grover et al } \\
(2013)^{24}\end{array}$ & $\begin{array}{l}\text { CLP } \\
n=331\end{array}$ & $\begin{array}{l}\text { - Inpatient mortality rate } 12.4 \% \\
\text { - In comparative analysis, inpatient mortality was associated with lower age(<65 years), } \\
\text { high rate of alcohol dependence, more frequent use of restrain prior to development } \\
\text { of delirium } \\
\text { - In regression analysis lower age (<65 years) and more frequent use of restrain prior to } \\
\text { development of delirium }\end{array}$ \\
\hline $\begin{array}{l}\text { Grover et al } \\
(2015)^{46}\end{array}$ & $\begin{array}{l}\text { CLP } \\
n=107 \\
\text { Elderly ( } \geq 60 \text { years) }\end{array}$ & $\begin{array}{l}\text { - Presence of premorbid cognitive deficits is more often associated with development } \\
\text { of delirium prior to getting admitted to the hospital, compared with those without } \\
\text { premorbid cognitive deficits } \\
\text { - Those with and without cognitive deficits prior to onset of delirium do not differ in } \\
\text { terms of frequency and severity of various symptoms of delirium, severity of delirium } \\
\text { as assessed by using DRS-R98, DRS-R98 cognitive domain score, DRS-R98 noncogni- } \\
\text { tive domain score, motoric subtypes, risk factors for development of delirium, various } \\
\text { associated etiologies, mean number of risk factors for delirium, and mean number of } \\
\text { associated etiologies }\end{array}$ \\
\hline $\begin{array}{l}\text { Grover et al } \\
(2014)^{44}\end{array}$ & $\begin{array}{l}\text { CLP } \\
n=98 \\
\text { Elderly } \geq 60 \text { years }\end{array}$ & $\begin{array}{l}\text { - Compared with hyperactive subtype, significantly higher proportion of patients with } \\
\text { hypoactive subtype had thought process abnormality and motor retardation } \\
\text { - When the hyperactive and mixed motoric subtype groups were compared, patients } \\
\text { with mixed subtype group had significantly higher prevalence of thought process } \\
\text { abnormality and motor retardation } \\
\text { - When hypoactive and mixed subtype were compared, patients with mixed subtype } \\
\text { had significant higher frequency of perceptual disturbances, delusions and motor } \\
\text { agitation } \\
\text { - The three motoric subtypes do not differ significantly, in terms of severity of cognitive } \\
\text { symptoms, however, there was some difference in the severity of noncognitive symp- } \\
\text { toms across the various motoric subtypes }\end{array}$ \\
\hline $\begin{array}{l}\text { Grover et al } \\
(2016)^{50}\end{array}$ & $\begin{array}{l}\mathrm{CLP} \\
n=76\end{array}$ & $\begin{array}{l}\text { - Attention deficits in patients with delirium influence the severity of cognitive and } \\
\text { noncognitive symptoms of delirium } \\
\text { - The mean HMSE score has significant correlation with DRS-R-98 severity score, DRS- } \\
\text { R-98 cognitive subscale score, DRS-R-98 noncognitive domain subscale score, and } \\
\text { DRS severity score without attention score. }\end{array}$ \\
\hline $\begin{array}{l}\text { Grover et al } \\
(2014)^{48}\end{array}$ & $\begin{array}{l}\text { CLP } \\
n=461 \\
\text { Retrospective }\end{array}$ & $\begin{array}{l}\text { - Longer duration of psychiatric referral after the onset of delirium is associated with: } \\
\text { older age, presence of and higher severity of sleep disturbance, presence of and higher } \\
\text { severity of motor retardation, presence of visuospatial disturbances, presence of fluctu- } \\
\text { ation of symptoms, being admitted to medical ward/medical intensive care units, and } \\
\text { absence of comorbid axis-1 psychiatry diagnoses } \\
\text { - In the regression analysis, longer duration of psychiatric referral after the onset of } \\
\text { delirium is associated with presence of sleep disturbance, presence motor retarda- } \\
\text { tion, being admitted to medical ward/medical intensive care units, and absence of } \\
\text { comorbid axis-1 psychiatry diagnoses }\end{array}$ \\
\hline
\end{tabular}


Table 5 (continued)

\begin{tabular}{|c|c|c|}
\hline Study (year) & Setting & Findings \\
\hline $\begin{array}{l}\text { Grover et al } \\
(2013)^{41}\end{array}$ & $\begin{array}{l}\text { CLP } \\
n=321 \text { (adult sample } \\
245 ; \text { geriatric } 76)\end{array}$ & $\begin{array}{l}\text { - When the patients in the adult and geriatric group were compared, no significant } \\
\text { difference was seen between the two groups, except for the adult group having sta- } \\
\text { tistically higher prevalence and severity scores for thought process abnormalities and } \\
\text { lability of affect } \\
\text { - The two groups were similar for the mean number of etiologies associated with } \\
\text { delirium } \\
\text { - When the two groups were compared for the etiological factors, patients in the adult } \\
\text { group more often had hepatic derangement, substance intoxication, withdrawal, and } \\
\text { postpartum causes; in contrast lung disease, and cardiac abnormalities were more } \\
\text { common in the elderly group }\end{array}$ \\
\hline $\begin{array}{l}\text { Grover et al } \\
(2014)^{25}\end{array}$ & $\begin{array}{l}\text { CLP } \\
n=49, \text { CAP }\end{array}$ & $\begin{array}{l}\text { - Different subtypes of delirium do not differ from each other in terms of frequency and } \\
\text { severity of various symptoms of delirium except for minor differences } \\
\text { - Compared with those with hypoactive delirium, those with hyperactive and mixed } \\
\text { subtype more often have hallucination }\end{array}$ \\
\hline $\begin{array}{l}\text { Rajlakshmi et al } \\
(2013)^{40}\end{array}$ & $\begin{array}{l}\text { CLP } \\
n=84\end{array}$ & $\begin{array}{l}\text { - Attention deficit is a core symptom of delirium } \\
\text { - Cognitive deficits are quite prevalent in patients with delirium and correlate with } \\
\text { overall severity of delirium }\end{array}$ \\
\hline $\begin{array}{l}\text { Grover et al } \\
(2014)^{45}\end{array}$ & $\begin{array}{l}\text { CLP } \\
n=205\end{array}$ & $\begin{array}{l}\text { - Two-fifths ( } n=80 ; 39 \% \text { ) of patients with delirium have two or more catatonic } \\
\text { symptoms } \\
\text { - When the diagnosis of catatonic syndrome was considered, } 32 \% \text { and } 12.7 \% \text { were } \\
\text { observed to have catatonia as per the Bush Francis Catatonia screening instrument } \\
\text { and DSM-5 criteria, respectively } \\
\text { - Catatonic syndrome was more common in women and in those who had onset of } \\
\text { delirium prior to hospitalization } \\
\text { - Among the delirium subtypes, hypoactive delirium was more commonly associated } \\
\text { with catatonic syndrome }\end{array}$ \\
\hline $\begin{array}{l}\text { Grover et al } \\
(2012)^{49}\end{array}$ & $\begin{array}{l}\text { CLP } \\
n=30 \\
\text { CAP }\end{array}$ & $\begin{array}{l}\text { - Compared with adults, children and adolescents had lower frequency of long-term } \\
\text { memory and visuospatial disturbances } \\
\text { - Compared with the elderly, children, and adolescents had higher frequency of lability } \\
\text { of affect } \\
\text { - In terms of severity of symptoms, compared with adults, the children and adoles- } \\
\text { cents have lower severity of sleep-wake disturbances, abnormality of thought, motor } \\
\text { agitation, orientation, attention, short-term memory, long-term memory, and visu- } \\
\text { ospatial abilities } \\
\text { - When compared with elderly, children and adolescents have higher severity of lability } \\
\text { of affect and lower severity of language disturbances, short-term memory, and visu- } \\
\text { ospatial abilities }\end{array}$ \\
\hline $\begin{array}{l}\text { Grover et al } \\
(2009)^{63}\end{array}$ & $\begin{array}{l}\text { CLP } \\
n=46 \\
\text { (retrospective) } \\
\text { CAP }\end{array}$ & $\begin{array}{l}\text { - The most common underlying pathology was various infections followed by } \\
\text { neoplasms } \\
\text { - Besides clouding of consciousness, all patients exhibited sleep-wake cycle distur- } \\
\text { bance and impaired orientation }\end{array}$ \\
\hline
\end{tabular}


Table 5 (continued)

\begin{tabular}{|c|c|c|}
\hline Study (year) & Setting & Findings \\
\hline $\begin{array}{l}\text { Grover et al } \\
(2009)^{12}\end{array}$ & $\begin{array}{l}n=3,092 \\
\text { Retrospective }\end{array}$ & $\begin{array}{l}\text { - The prevalence of delirium in all inpatients ranged from } 0.28 \text { to } 0.53 \% \text { (mean }= \\
0.44 \% \text { ), with higher prevalence among the elderly } \\
\text { - Delirium forms the largest diagnostic category ( } 30.77-38.95 \% \text { ) of all referred cases } \\
\text { with a mean of } 33.96 \% \\
\text { - In } 80 \% \text { of the cases, the referral for delirium was made for abnormal behavior or } \\
\text { patient's noncooperation for treatment }\end{array}$ \\
\hline $\begin{array}{l}\text { Grover et al } \\
(2014)^{29}\end{array}$ & $\begin{array}{l}\text { CLP } \\
n=321\end{array}$ & $\begin{array}{l}\text { - When the hyperactive and hypoactive subtypes of delirium were compared, patients } \\
\text { with hyperactive delirium had significantly higher prevalence of perceptual distur- } \\
\text { bances, delusions, lability of affect and motor agitation; however, patients with hypo- } \\
\text { active delirium had higher prevalence of thought process abnormality and motor } \\
\text { retardation } \\
\text { - When hyperactive and the mixed subtype were compared, significantly higher preva- } \\
\text { lence of thought process abnormality and motor retardation were seen in the mixed } \\
\text { subtype group } \\
\text { - When the mixed and hypoactive subtype were compared, patients with mixed sub- } \\
\text { type had significantly higher prevalence of perceptual disturbances, delusions, lability } \\
\text { of affect, and motor agitation } \\
\text { - No significant differences emerged for the cognitive symptoms as assessed on DRS-R- } \\
98 \text { across the different motoric subtypes }\end{array}$ \\
\hline $\begin{array}{l}\text { Grover et al } \\
(2013)^{64}\end{array}$ & $\begin{array}{l}\text { CLP } \\
n=100 \text { (replication } \\
\text { study) }\end{array}$ & - Validation of DMSS \\
\hline $\begin{array}{l}\text { Meagher et al } \\
(2014)^{65}\end{array}$ & $\begin{array}{l}\text { CLP } \\
n=487\end{array}$ & - Development of abbre \\
\hline $\begin{array}{l}\text { Gupta et al } \\
(2010)^{66}\end{array}$ & $\begin{array}{l}\mathrm{CLP} \\
n=80\end{array}$ & $\begin{array}{l}\text { - Factors which predict delayed diagnosis of delirium include prevalent delirium at } \\
\text { admission, sleep-wake disturbance, and specialty of referral }\end{array}$ \\
\hline $\begin{array}{l}\text { Meagher et al } \\
(2014)^{67}\end{array}$ & $\begin{array}{l}\text { CLP } \\
n=768 \\
\text { Retrospective }\end{array}$ & $\begin{array}{l}\text { - Evaluated the concordance between DSM-IV and DSM-5 criteria of delirium } \\
\text { - The concordance between DSM-IV and DSM-5 criteria varies considerably depending } \\
\text { on the interpretation of criteria } \\
\text { - Overly strict adherence to the text detail, as described in DSM-5, can lead to reduction } \\
\text { in the number of cases diagnosed with delirium; however, a more "relaxed" approach } \\
\text { renders DSM-5 criteria comparable to DSM-IV criteria with minimal impact on their } \\
\text { actual application and is thus recommended }\end{array}$ \\
\hline $\begin{array}{l}\text { Khurana et al } \\
(2002)^{68}\end{array}$ & $\begin{array}{l}\text { Medical-surgical } \\
\text { ward } \\
n=100\end{array}$ & $\begin{array}{l}\text { - Risk factors for delirium: preexisting cognitive deficits, neurological illnesses, urinary } \\
\text { tract infections, visual impairment, hearing impairment, current proteinuria, leucocy- } \\
\text { tosis, raised blood ammonia, hyponatremia, and potassium level disturbances }\end{array}$ \\
\hline $\begin{array}{l}\text { Kumar et al } \\
(2015)^{54}\end{array}$ & $n=80$ & $\begin{array}{l}\text { - Risk factors commonly associated with hyperactive subtype: alcohol and other sub- } \\
\text { stance use disorders } \\
\text { - Risk factors commonly associated with hypoactive subtype: other psychiatric dis- } \\
\text { orders such as schizophrenia and mood disorders, infection, and chronic medical } \\
\text { conditions } \\
\text { - Compared with hyperactive subtype, cognitive impairments were significantly higher } \\
\text { among those with hypoactive subtype }\end{array}$ \\
\hline Rai et al $(2014)^{13}$ & $\begin{array}{l}\text { Neurology inpatient } \\
\text { setting } \\
n=52 \\
\text { Mean age }=65 \text { years }\end{array}$ & $\begin{array}{l}\text { - Factors frequently associated with delirium are leucocytosis and hyponatremia } \\
\text { - Duration of hospital stay is longer and mortality rate is higher in patients of delirium } \\
\text { in whom cause of delirium could not be ascertained }\end{array}$ \\
\hline
\end{tabular}


Table 5 (continued)

\begin{tabular}{|c|c|c|}
\hline Study (year) & Setting & Findings \\
\hline $\begin{array}{l}\text { Mushtaq et al } \\
(2014)^{55}\end{array}$ & $\begin{array}{l}\text { Medical-surgical } \\
\text { inpatients } \\
n=40 \text { (in the } \\
\text { delirium group) }\end{array}$ & $\begin{array}{l}\text { - Hypoactive delirium had more cognitive impairment compared with hyperactive } \\
\text { delirium }(p=0.001)\end{array}$ \\
\hline \multicolumn{3}{|l|}{ Postoperative } \\
\hline $\begin{array}{l}\text { Dhakharia et al } \\
(2017)^{32}\end{array}$ & $\begin{array}{l}\text { Postoperative stage } \\
\text { after cancer surgery } \\
n=824\end{array}$ & $\begin{array}{l}\text { - Postoperative delirium is significantly associated with older age, history of addiction, } \\
\text { presence of respiratory complications, sepsis, ICU stay }>24 \text { hours }(p<0.05) \text {, and elec- } \\
\text { trolyte impairment }(p<0.05)\end{array}$ \\
\hline $\begin{array}{l}\text { Chrispal et al } \\
(2010)^{34}\end{array}$ & $\begin{array}{l}\text { Delirium in patient } \\
\text { undergoing hip } \\
\text { fractures surgery } \\
n=81 \\
\text { Elderly ( } \geq 60 \text { years) }\end{array}$ & $\begin{array}{l}\text { - Risk factors for delirium: presence of dementia, duration of surgery }>2.5 \text { and preoper- } \\
\text { ative packed cell volume }<25(\mathrm{OR}=8.07) \\
\text { - Precipitating factors: postoperative infections, metabolic abnormalities and vascular } \\
\text { events } \\
\text { - Patients with delirium had longer hospital stays and poor ambulation at discharge }\end{array}$ \\
\hline $\begin{array}{l}\text { Khanna et al, } \\
(2018)^{35}\end{array}$ & $n=100$ & $\begin{array}{l}\text { - Longer duration of preoperative fasting duration is a risk factor for postoperative } \\
\text { emergence delirium in children undergoing ophthalmic examination undergeneral } \\
\text { anesthesia with sevoflurane }\end{array}$ \\
\hline \multicolumn{3}{|c|}{ Studies focusing on health professionals } \\
\hline $\begin{array}{l}\text { Chawla et al } \\
(2014)^{69}\end{array}$ & $\begin{array}{l}\text { Survey of ICU } \\
\text { clinicians } \\
n=659\end{array}$ & $\begin{array}{l}\text { - Majority (65.6\%) of the responders reported that they were not assessing delirium in } \\
\text { the ICU regularly } \\
\text { - About two-thirds of the responders (65\%) considered that the incidence of delirium in } \\
\text { mechanically ventilated patients is less than } 10 \% ; 31 \% \text { responders reported incidence } \\
\text { of delirium in mechanically ventilated patients was in the range of } 10-50 \text { and only } \\
2 \% \text { of the responders reported that more than half of their mechanically ventilated } \\
\text { patients experience delirium } \\
\text { - } 73 \% \text { responders responded when asked about use of delirium scale } \\
\text { - Confusion Assessment Method-ICU (CAM-ICU) was the most preferred method of } \\
\text { delirium assessment } \\
\text { - Haloperidol was the most commonly used agent for delirium } \\
\text { - Majority of the respondents were aware of the benefit of early mobilization, but lack } \\
\text { of support staff, and safety concerns were the main obstacles to its implementation }\end{array}$ \\
\hline $\begin{array}{l}\text { Morandi et al } \\
(2017)^{70}\end{array}$ & $n=1,521$ clinicians & $\begin{array}{l}\text { - Worldwide ABCDEF (Assessing Pain, Both Spontaneous Awakening and Breathing } \\
\text { Trials, Choice of Drugs, Delirium monitoring/management, Early exercise/mobility, } \\
\text { and Family Empowerment) survey } \\
\text { - Delirium monitoring was implemented in } 70 \% \text { of ICUs, but only } 42 \% \text { used a validated } \\
\text { delirium tool. } \\
\text { - Although India specific data are not available, in Asia } 80 \% \text { of the clinicians implemented } \\
\text { delirium monitoring, with CAM-ICU being the most common scale for assessment } \\
\text { - From Asia, only } 2 \% \text { of the clinicians believed that }>60 \% \text { of the patients in the ICU have } \\
\text { delirium }\end{array}$ \\
\hline $\begin{array}{l}\text { Varghese et al } \\
(2014)^{71}\end{array}$ & $n=32$ & $\begin{array}{l}\text { - Educational program for nurses } \\
\text { - Providing knowledge about delirium to the nurses was associated with significant } \\
\text { improvement in the knowledge and practice of nurses toward delirium among the } \\
\text { nurses in the educational group. }\end{array}$ \\
\hline
\end{tabular}


Table 5 (continued)

\begin{tabular}{|c|c|c|}
\hline Study (year) & Setting & Findings \\
\hline \multicolumn{3}{|c|}{ Patient's experience of delirium } \\
\hline $\begin{array}{l}\text { Grover et al, } \\
(2019)^{26}\end{array}$ & $\begin{array}{l}\text { CLP } \\
n=103\end{array}$ & $\begin{array}{l}\text { - 30.5\% of the patients had substantial symptoms of PTSD, } 22 \%(n=13) \text { had probable } \\
\text { symptoms of PTSD and } 15.3 \% \text { were considered to have partial symptoms of PTSD } \\
\text { after resolution of delirium } \\
\text { - When those with and without PTSD were compared, those with PTSD symptoms had } \\
\text { significantly higher prevalence of fluctuation of symptoms, while experiencing delirium } \\
\text { and had significantly higher mean scores for the items of motor agitation, attentional } \\
\text { deficits, higher total severity score on the DRS-R-98 and higher DRS-R-98 total score. } \\
\text { Higher severity of delirium was associated with higher severity of PTSD symptoms }\end{array}$ \\
\hline $\begin{array}{l}\text { Grover and Shah } \\
(2011)^{72}\end{array}$ & $\begin{array}{l}\text { CLP } \\
n=53, \text { patients with } \\
\text { delirium }\end{array}$ & $\begin{array}{l}\text { - } 28.3 \% \text { of patients remembered themselves to be confused and rest had no recollec- } \\
\text { tion of the same } \\
\text { - Those who could remember their experience had moderate }(26.7 \%) \text {, severe ( } 40.0 \%) \\
\text { and very severe ( } 33.3 \%) \text { level of distress } \\
\text { - Of those who could not remember their delirium experience, most of them had mod- } \\
\text { erate ( } 44.7 \%) \text { to severe ( } 26.3 \%) \text { distress. Those who remembered their experience in } \\
\text { general described it as a state of fearfulness, anxiety, confusion and feeling strange }\end{array}$ \\
\hline $\begin{array}{l}\text { Grover et al } \\
(2015)^{53}\end{array}$ & $\begin{array}{l}\text { CLP } \\
n=203\end{array}$ & $\begin{array}{l}\text { - One-third (35\%) of the patients were able to recollect their experiences during the } \\
\text { delirium, and the majority ( } 86 \% \text { ) of them were distressed by these experiences } \\
\text { - About half of the patients who reported the experience to be distressing reported it } \\
\text { to be of moderate level of distress } \\
\text { - The most common distressing themes which were recollected were fear and visual } \\
\text { hallucination. When the patients who could recall and who could not recall their expe- } \\
\text { rience of delirium were compared, recall of delirium experience was associated with } \\
\text { a higher prevalence of perceptual and language disturbances and a higher severity of } \\
\text { delirium }\end{array}$ \\
\hline \multicolumn{3}{|c|}{ Studies focusing on caregivers } \\
\hline $\begin{array}{l}\text { Grover and Shah } \\
(2013)^{73}\end{array}$ & $\begin{array}{l}n=72 \text { caregivers } \\
\text { of } 53 \text { patients with } \\
\text { delirium } \\
\text { CLP }\end{array}$ & $\begin{array}{l}\text { - Symptoms of delirium that led to severe or very severe distress in more than two } \\
\text { thirds of the caregivers included decreased sleep, increased motor activity, attempts } \\
\text { to remove intravenous lines, tubings, and attempts to get out of bed when they were } \\
\text { actually required to lie down }\end{array}$ \\
\hline $\begin{array}{l}\text { Grover and Shah } \\
(2012)^{47}\end{array}$ & $\begin{array}{l}n=72 \text { caregivers } \\
\text { CLP }\end{array}$ & $\begin{array}{l}\text { - About one-third of the caregivers (36.11\%) attributed the symptoms of delirium to } \\
\text { nonorganic causes like supernatural beliefs, emotional stress resulting from physical illness } \\
\text { or various social factors, attention seeking behavior, or a result of religious disobedience }\end{array}$ \\
\hline
\end{tabular}

Abbreviations: APACHE, Acute Physiology and Chronic Health Evaluation; AWD, alcohol withdrawal delirium; CAM-ICU, confusion assessment method for the intensive care unit; CAP, children and adolescents; CCU, coronary care unit; Cl, confidence interval; CLP, consultation liaison psychiatry; DMSS, delirium motor symptom scale; DRS-R-98, delirium rating scale revised-1998; ICDSC, intensive care delirium screening checklist; ICU, intensive care unit; MMSE, Mini Mental State Examination; MRI, magnetic resonance imaging; OR, odds ratio; PTSD, posttraumatic stress order; RICU, respiratory intensive care unit; ROC, receiver operating curve; SOFA, Sequential Organ Failure Assessment. 
Table 6 Efficacy of various medications in management of delirium

\begin{tabular}{|c|c|c|c|c|c|c|c|}
\hline $\begin{array}{l}\text { Study } \\
\text { (year) }\end{array}$ & $\begin{array}{l}\text { Medications } \\
\text { compared }\end{array}$ & Sample size & $\begin{array}{l}\text { Diagnostic } \\
\text { measure }\end{array}$ & Trial design & Setting & $\begin{array}{l}\text { Outcome } \\
\text { measure }\end{array}$ & Outcome \\
\hline $\begin{array}{l}\text { Jain et al } \\
(2017)^{74}\end{array}$ & $\begin{array}{l}\text { Haloperidol } \\
(1-4 \text { mg/day }) \\
\text { vs. olanzapine } \\
(2.5-10 \mathrm{mg} / \\
\text { day })\end{array}$ & $\begin{array}{l}\text { Haloperidol }(n= \\
53) \\
\text { Olanzapine }(n=47)\end{array}$ & DSM-IV & $\begin{array}{l}\text { Open-label } \\
\text { RCT }\end{array}$ & CLP & MDAS & $\begin{array}{l}\text { - Both medications effective } \\
\text { in management of delirium } \\
\text { - Haloperidol } \approx \text { olanzapine }\end{array}$ \\
\hline $\begin{array}{l}\text { Grover et al } \\
(2016)^{75}\end{array}$ & $\begin{array}{l}\text { Haloperidol } \\
(0.25-1.25 \\
\text { mg/day) vs. } \\
\text { quetiapine } \\
(12.5-75 \mathrm{mg} / \\
\text { day) }\end{array}$ & $\begin{array}{l}\text { Haloperidol }(n= \\
32) \\
\text { Quetiapine }(n=31)\end{array}$ & DSM-IV & $\begin{array}{l}\text { Single-blind } \\
\text { RCT }\end{array}$ & CLP & $\begin{array}{l}\text { DRS-R-98 } \\
\text { MMSE }\end{array}$ & $\begin{array}{l}\text { - Both medications effective } \\
\text { in management of delirium } \\
\text { - Haloperidol } \approx \text { quetiapine }\end{array}$ \\
\hline $\begin{array}{l}\text { Grover et al } \\
(2011)^{76}\end{array}$ & $\begin{array}{l}\text { Haloperidol } \\
(0.25-10 \\
\text { mg/day) vs. } \\
\text { olanzapine } \\
(1.25-20 \\
\text { mg/day) vs. } \\
\text { risperidone } \\
(0.25-4 \mathrm{mg} / \\
\text { day) }\end{array}$ & $\begin{array}{l}\text { Haloperidol }(n= \\
21) \\
\text { Olanzapine }(n=23) \\
\text { Risperidone }(n= \\
20)\end{array}$ & DSM-IV & $\begin{array}{l}\text { Single-blind } \\
\text { RCT }\end{array}$ & CLP & $\begin{array}{l}\text { DRS-R-98 } \\
\text { MMSE }\end{array}$ & $\begin{array}{l}\text { - All the medications effec- } \\
\text { tive in management of } \\
\text { delirium } \\
\text { - Haloperidol } \approx \text { olanzapine } \\
\approx \text { risperidone }\end{array}$ \\
\hline $\begin{array}{l}\text { Gupta et al } \\
(2005)^{77}\end{array}$ & $\begin{array}{l}\text { Risperidone } \\
(0.5-2 \mathrm{mg} / \\
\text { day })\end{array}$ & Risperidone $(n=7)$ & - & $\begin{array}{l}\text { Retrospective } \\
\text { study }\end{array}$ & CLP & - & $\begin{array}{l}\text { - Six out of the seven } \\
\text { patients were either signifi- } \\
\text { cantly improved or recov- } \\
\text { ered at the last follow-up }\end{array}$ \\
\hline $\begin{array}{l}\text { Vijaykumar } \\
\text { et al }(2016)^{78}\end{array}$ & $\begin{array}{l}\text { Melatonin (3 } \\
\text { mg/day) vs. } \\
\text { placebo }\end{array}$ & $\begin{array}{l}\text { Melatonin }(n=26) \\
\text { Placebo }(n=26)\end{array}$ & - & DBRCT & $\begin{array}{l}\text { ICU } \\
\text { Delirium in } \\
\text { patients with } \\
\text { organo- } \\
\text { phosphorus } \\
\text { poisoning }\end{array}$ & CAM-ICU & $\begin{array}{l}\text { - Patients receiving mel- } \\
\text { atonin had significantly } \\
\text { lower time to be delirium } \\
\text { free compared with pla- } \\
\text { cebo group } \\
\text { - Prevalence of delirium was } \\
\text { significantly lower in the } \\
\text { melatonin group, com- } \\
\text { pared with the placebo } \\
\text { group after day } 3\end{array}$ \\
\hline
\end{tabular}

Abbreviations: $\approx$ No statistically significant difference; CAM-ICU, confusion assessment method for the intensive care unit; CLP, consultation liaison psychiatry; DBRCT, double-blind randomized controlled trial; DRS-R-98, delirium rating scale revised-1998; DSM IV, diagnostic and statistical manual of mental disorders, fourth edition; MDAS, memorial delirium rating scale; MMSE, mini metal state examination;

Table 7 Studies evaluating the efficacy of various measures in prevention of emergence delirium

\begin{tabular}{|c|c|c|c|c|c|c|}
\hline Study (year) & $\begin{array}{l}\text { Medications } \\
\text { compared }\end{array}$ & Sample size & Trial design & Setting & $\begin{array}{l}\text { Outcome } \\
\text { measure }\end{array}$ & Outcome \\
\hline $\begin{array}{l}\text { Avidan et al } \\
(2017)^{79}\end{array}$ & $\begin{array}{l}\text { Placebo (normal saline) } \\
\text { vs. low-dose ketamine } \\
(0.5 \mathrm{mg} / \mathrm{kg}) \text { vs. high } \\
\text { dose } \mathrm{ketamine} \\
(1.0 \mathrm{mg} / \mathrm{kg})\end{array}$ & $\begin{array}{l}\text { Placebo }(n=222) \\
\text { Low-dose ketamine } \\
(n=227) ; \text { High- } \\
\text { dose ketamine } \\
(n=223)\end{array}$ & $\begin{array}{l}\text { Multicentric } \\
\text { DBRCT }\end{array}$ & Postsurgical & $\begin{array}{l}\text { CAM, } \\
\text { CAM-ICU }\end{array}$ & $\begin{array}{l}\text { - No decrease } \\
\text { delirium in older } \\
\text { adults after } \\
\text { major surgery } \\
\text { - Might cause } \\
\text { harm by induc- } \\
\text { ing negative } \\
\text { experiences }\end{array}$ \\
\hline $\begin{array}{l}\text { Gonsalvez } \\
\text { et al }(2018)^{80}\end{array}$ & $\begin{array}{l}\text { Midazolam at the } \\
\text { induction }(0.03 \mathrm{mg} / \mathrm{kg}) \\
\text { vs. midazolam } \\
(0.03 \mathrm{mg} / \mathrm{kg}) \\
\text { administered } \\
10 \text { minutes before the } \\
\text { end of surgery }\end{array}$ & $\begin{array}{l}\text { At Induction } \\
(n=40) \text { and } \\
10 \text { minutes before } \\
\text { the end of surgery } \\
(n=40)\end{array}$ & DBRCT & $\begin{array}{l}\text { Pediatric } \\
\text { surgery }\end{array}$ & PAED scale & $\begin{array}{l}\text { - No difference } \\
\text { between the } \\
\text { two groups in } \\
\text { the incidence of } \\
\text { emergence delir- } \\
\text { ium in children } \\
\text { undergoing } \\
\text { sevoflurane } \\
\text { anesthesia }\end{array}$ \\
\hline
\end{tabular}


Table 7 (Continued)

\begin{tabular}{|c|c|c|c|c|c|c|}
\hline Study (year) & $\begin{array}{l}\text { Medications } \\
\text { compared }\end{array}$ & Sample size & Trial design & Setting & $\begin{array}{l}\text { Outcome } \\
\text { measure }\end{array}$ & Outcome \\
\hline $\begin{array}{l}\text { Makkar et al } \\
(2015)^{81}\end{array}$ & $\begin{array}{l}\text { Dexmedetomidine } \\
(0.3 \mu \mathrm{g} / \mathrm{kg}) \text { vs. propofol } \\
(1 \mathrm{mg} / \mathrm{kg}) \text { vs. saline } \\
0.9 \%\end{array}$ & $\begin{array}{l}\text { Dexmedetomidine } \\
(n=32) \\
\text { Propofol }(n=36) \\
\text { Saline }(n=32)\end{array}$ & RCT & $\begin{array}{l}\text { Pediatric } \\
\text { surgery } \\
\text { (infraumbilical } \\
\text { surgery) }\end{array}$ & PAED scale & $\begin{array}{l}\text { - Compared with } \\
\text { normal saline, } \\
\text { dexmedeto- } \\
\text { midine leads } \\
\text { to significant } \\
\text { reduction in } \\
\text { the incidence } \\
\text { of emergence } \\
\text { delirium but } \\
\text { this occurs } \\
\text { at the cost } \\
\text { of higher } \\
\text { incidence of } \\
\text { sedation in the } \\
\text { recovery period }\end{array}$ \\
\hline $\begin{array}{l}\text { Trivedi et al } \\
(2016)^{82}\end{array}$ & $\begin{array}{l}\text { Group K: premedica- } \\
\text { tion with inj. glyco- } \\
\text { pyrrolate } 0.01 \mathrm{mg} / \mathrm{kg} \text {, } \\
\text { inj. ketamine } 2 \mathrm{mg} / \mathrm{kg} \\
\text { Group M: premedica- } \\
\text { tion with inj. glyco- } \\
\text { pyrrolate } 0.01 \mathrm{mg} / \mathrm{kg} \\
\text { and inj. midazolam } \\
0.05 \mathrm{mg} / \mathrm{kg} \text {, inj. keta- } \\
\text { mine } \\
2 \mathrm{mg} / \mathrm{kg} \text {, } \\
\text { Group D: after } \\
\text { premedication with } \\
\text { inj. glycopyrrolate } \\
0.01 \mathrm{mg} / \mathrm{kg} \text { and inj. } \\
\text { dexmedetomidine } \\
0.5 \mu \mathrm{g} / \mathrm{kg} \text {, ketamine } \\
2 \mathrm{mg} / \mathrm{kg}\end{array}$ & $\begin{array}{l}\text { Group K }(n=30) \\
\text { Group M }(n=30) \\
\text { Group D }(n=30)\end{array}$ & DBRCT & $\begin{array}{l}\text { Surgical setting } \\
\text { (patients } \\
\text { undergoing } \\
\text { laparoscopic } \\
\text { ligation, skin } \\
\text { grafting, } \\
\text { dilatation and } \\
\text { curettage, } \\
\text { endoscopic } \\
\text { procedures, } \\
\text { and excision of } \\
\text { small swelling) }\end{array}$ & MDAS & $\begin{array}{l}\text { - Incidence of } \\
\text { delirium was } \\
\text { least with use } \\
\text { of dexmede- } \\
\text { tomidine, and } \\
\text { the difference } \\
\text { was statistically } \\
\text { significant com- } \\
\text { pared with the } \\
\text { ketamine only } \\
\text { group } \\
\text { - Incidence of } \\
\text { delirium was } \\
\text { also lower } \\
\text { with use of } \\
\text { midazolam } \\
\text { compared with } \\
\text { the ketamine } \\
\text { only group }\end{array}$ \\
\hline $\begin{array}{l}\text { Prabhu and } \\
\text { Mehandale } \\
(2017)^{83}\end{array}$ & $\begin{array}{l}\text { Comparison of oral } \\
\text { dexmedetomidine } \\
(4 \mu \mathrm{g} / \mathrm{kg}) \mathrm{vs} \text {. oral } \\
\text { midazolam }(0.5 \mathrm{mg} / \mathrm{kg}) \\
\text { as premedication to } \\
\text { prevent emergence } \\
\text { agitation after } \\
\text { sevoflurane anesthesia } \\
\text { in pediatric patients }\end{array}$ & $\begin{array}{l}\text { Midazolam }(n=45) \\
\text { Dexmedetomidine } \\
(n=45)\end{array}$ & DBRCT & Postoperative & PAED scale & $\begin{array}{l}\text { - Compared with } \\
\text { midazolam, } \\
\text { dexmedeto- } \\
\text { midine was } \\
\text { associated with } \\
\text { lower incidence } \\
\text { of emergence } \\
\text { agitation }\end{array}$ \\
\hline $\begin{array}{l}\text { Sinha and } \\
\text { Sood }(2012)^{84}\end{array}$ & $\begin{array}{l}\text { Comparison of } \\
\text { caudal block with } \\
\text { bupivacaine }(0.25 \% \\
0.5 \mathrm{~mL} / \mathrm{kg}) \mathrm{vs} . \text { bupivacaine } \\
(0.25 \% 0.5 \mathrm{~mL} / \mathrm{kg}) \text { and } \\
\text { ketamine }(0.5 \mathrm{~mL} / \mathrm{kg}) \\
\text { and no caudal block } \\
\text { in pediatric anesthesia } \\
\text { with sevoflurane }\end{array}$ & $\begin{array}{l}n=150 \\
\text { Children }\end{array}$ & DBRCT & Postoperative & PAED scale & $\begin{array}{l}\text { - Compared with } \\
\text { use of bupi- } \\
\text { vacaine only, } \\
\text { use of adjuvant } \\
\text { Ketamine } \\
\text { along with } \\
\text { bupivacaine, } \\
\text { is protective } \\
\text { against emer- } \\
\text { gence delirium } \\
\text { children, follow- } \\
\text { ing sevoflurane } \\
\text { anesthesia }\end{array}$ \\
\hline
\end{tabular}


Table 7 (Continued)

\begin{tabular}{|c|c|c|c|c|c|c|}
\hline Study (year) & $\begin{array}{l}\text { Medications } \\
\text { compared }\end{array}$ & Sample size & Trial design & Setting & $\begin{array}{l}\text { Outcome } \\
\text { measure }\end{array}$ & Outcome \\
\hline $\begin{array}{l}\text { Perumal et al } \\
(2015)^{85}\end{array}$ & $\begin{array}{l}\text { Midazolam premedica- } \\
\text { tion }(0.02 \mathrm{mg} / \mathrm{kg} \text { iv) for } \\
\text { ketamine-induced ( } 1 \\
\mathrm{mg} / \mathrm{kg} \text { ) emergence }\end{array}$ & $\begin{array}{l}n=30 \\
\text { Adult }\end{array}$ & $\begin{array}{l}\text { Observational } \\
\text { study }\end{array}$ & Postoperative & $\begin{array}{l}\text { Self- } \\
\text { designed } \\
\text { criteria } \\
\text { (presence } \\
\text { of pur- } \\
\text { poseless } \\
\text { and hallu- } \\
\text { cinatory } \\
\text { behavior) }\end{array}$ & $\begin{array}{l}\text { - Mild emergence } \\
\text { delirium was } \\
\text { noted in } 13.3 \% \\
\text { of patients at } \\
30 \text { minutes, } \\
\text { incidence of } \\
\text { which increased } \\
\text { to } 16.7 \% \text { at } 1 \\
\text { hour, which } \\
\text { reduced to } \\
13.3 \% \text { at } 2 \text { hours }\end{array}$ \\
\hline $\begin{array}{l}\text { Mukherjee et } \\
\text { al }(2015)^{86}\end{array}$ & $\begin{array}{l}\text { Intranasal dexmedeto- } \\
\text { midine }(1 \mu \mathrm{g} / \mathrm{kg}) \text { and } \\
\text { clonidine }(4 \mu \mathrm{g} / \mathrm{kg}) \text { in } \\
\text { patients receiving sevo- } \\
\text { flurane-based general } \\
\text { anesthesia }\end{array}$ & $n=80$ & $\begin{array}{l}\text { Double-blind } \\
\text { parallel group } \\
\text { study }\end{array}$ & Postoperative & PAED scale & $\begin{array}{l}\text { - Incidences of } \\
\text { emergence } \\
\text { delirium were } \\
\text { significantly } \\
\text { lower in the } \\
\text { dexmedeto- } \\
\text { midine group, } \\
\text { when compared } \\
\text { with clonidine } \\
\text { up to the first } \\
15 \text { minutes; } \\
\text { however, } \\
\text { later the two } \\
\text { groups were } \\
\text { comparable } \\
\text { - Overall com- } \\
\text { pared with dex- } \\
\text { medetomidine } \\
\text { group, higher } \\
\text { proportion of } \\
\text { patients in the } \\
\text { clonidine group } \\
\text { had emergence } \\
\text { delirium }\end{array}$ \\
\hline Study (year) & $\begin{array}{l}\text { Medications } \\
\text { compared }\end{array}$ & Sample size & Trial design & Setting & $\begin{array}{l}\text { Outcome } \\
\text { measure }\end{array}$ & Outcome \\
\hline $\begin{array}{l}\text { Begum et al } \\
(2019)^{87}\end{array}$ & $\begin{array}{l}\text { Bolus dexmedeto- } \\
\text { midine }(0.4 \mu \mathrm{g} / \mathrm{kg}) \\
\text { vs. low-dose Infusion } \\
(0.4 \mu \mathrm{g} / \mathrm{kg} / \mathrm{h}) \text { in } \\
\text { children undergoing } \\
\text { sevoflurane anesthesia }\end{array}$ & $n=48$ & DBRCT & Postoperative & PAED scale & $\begin{array}{l}\text { Compared with } \\
\text { children who } \\
\text { received low } \\
\text { dose infusion, } \\
\text { those who } \\
\text { received bolus } \\
\text { dexmedetomi- } \\
\text { dine had lower } \\
\text { proportion of } \\
\text { patients with } \\
\text { PAED scale } \\
\text { score of }>10\end{array}$ \\
\hline $\begin{array}{l}\text { Shenoy et al } \\
(2018)^{88}\end{array}$ & $\begin{array}{l}\text { Transversus abdominis } \\
\text { plane block supple- } \\
\text { mentation during } \\
\text { iliac crest bone graft } \\
\text { harvesting } \\
\text { Additional TAP block } \\
\text { along with local } \\
\text { infiltration Vs. wound } \\
\text { infiltration only }\end{array}$ & $n=143$ & $\begin{array}{l}\text { Simple ran- } \\
\text { dom sampling }\end{array}$ & Postoperative & $\begin{array}{l}\text { Watch a } \\
\text { scale score } \\
\text { of }>2\end{array}$ & $\begin{array}{l}\text { - Compared } \\
\text { with the } \\
\text { control group, } \\
\text { emergence } \\
\text { delirium was } \\
\text { lower among } \\
\text { the patients } \\
\text { who received } \\
\text { TAP block ( } 2.4 \\
\text { vs. } 9.5 \%)\end{array}$ \\
\hline
\end{tabular}


Table 7 (Continued)

\begin{tabular}{|c|c|c|c|c|c|c|}
\hline Study (year) & $\begin{array}{l}\text { Medications } \\
\text { compared }\end{array}$ & Sample size & Trial design & Setting & $\begin{array}{l}\text { Outcome } \\
\text { measure }\end{array}$ & Outcome \\
\hline $\begin{array}{l}\text { Priye et al } \\
(2015)^{89}\end{array}$ & $\begin{array}{l}\text { Dexmedetomidine as } \\
\text { an adjunct in post- } \\
\text { operative analgesia } \\
\text { following cardiac } \\
\text { surgery: } 12 \text {-hour infu- } \\
\text { sion of normal saline } \\
\text { and group-B received } \\
\text { a } 12 \text {-hour infusion of } \\
\text { dexmedetomidine } \\
0.4 \mu \mathrm{g} / \mathrm{kg} / \mathrm{h}\end{array}$ & $n=64$ & $\begin{array}{l}\text { Double-blind } \\
\text { study }\end{array}$ & Postoperative & RASS & $\begin{array}{l}\text { Although the } \\
\text { incidence of } \\
\text { delirium with } \\
\text { dexmedetomi- } \\
\text { dine was less, } \\
\text { both the groups } \\
\text { did not differ } \\
\text { statistically }\end{array}$ \\
\hline $\begin{array}{l}\text { Sharma et al } \\
(2019)^{90}\end{array}$ & $\begin{array}{l}\text { Single dose of dexme- } \\
\text { detomidine } 1 \mu \mathrm{g} / \mathrm{kg} \\
\text { vs. volume matched } \\
\text { saline for intraoper- } \\
\text { ative hemodynamic } \\
\text { and postoperative } \\
\text { recovery profile in } \\
\text { children undergoing } \\
\text { adenotonsillectomy }\end{array}$ & $\begin{array}{l}n=60 \\
\text { Children }\end{array}$ & $\begin{array}{l}\text { Placebo- } \\
\text { controlled } \\
\text { study }\end{array}$ & $\begin{array}{l}\text { Intra- and } \\
\text { postoperative }\end{array}$ & PAED scale & $\begin{array}{l}\text { - Compared with } \\
\text { control group, } \\
\text { decrease in } \\
\text { postoperative } \\
\text { EA without } \\
\text { causing any } \\
\text { excessive seda- } \\
\text { tion, desatu- } \\
\text { ration, or any } \\
\text { other drug-re- } \\
\text { lated adverse } \\
\text { events }\end{array}$ \\
\hline $\begin{array}{l}\text { Singh et al } \\
(2012)^{91}\end{array}$ & $\begin{array}{l}\text { EA in pediatric patients } \\
\text { under isoflurane, sevo- } \\
\text { flurane or desflurane } \\
\text { anesthesia }\end{array}$ & $\begin{array}{l}n=75 \text { ( } 3 \text { groups of } \\
25 \text { each) } \\
\text { Children }\end{array}$ & DBRCT & Postoperative & PAED scale & $\begin{array}{l}\text { - Incidence } \\
\text { and intensity } \\
\text { of EA were } \\
\text { comparable in } \\
\text { all three groups }\end{array}$ \\
\hline
\end{tabular}

Abbreviations: CAM, confusion assessment method; CAM-ICU, confusion assessment method for the intensive care unit; DBRCT, double blind randomized controlled trial; EA, emergence agitation; Inj., injection; MDAS, memorial delirium assessment scale; PAED, pediatric anesthesia emergency department; RASS, Richmond agitation-sedation scale; TAP, transversus abdominis plane.

Table 8 Case reports focusing on delirium

\begin{tabular}{|c|c|c|}
\hline & Study (year) & Findings \\
\hline \multicolumn{3}{|c|}{ Medication associated delirium } \\
\hline 1 & Kasim et al (2019) ${ }^{92}$ & Levetiracetam associated delirium in an elderly \\
\hline 2 & Ghoshal et al (2015) $)^{93}$ & Levofloxacin induced anaphylaxis and acute delirium \\
\hline 3 & Raj and Murthy $(2013)^{94}$ & Levofloxacin induced delirium \\
\hline 4 & Chowdhry et al $(2015)^{95}$ & Fluoroquinolones: an underrecognized cause for delirium \\
\hline 5 & Nasiruddin et al $(2014)^{96}$ & $\begin{array}{l}\text { Acute delirium in an elderly woman following zoledronate } \\
\text { administration }\end{array}$ \\
\hline 6 & Kaur et al $(2017)^{97}$ & Delirium induced by albendazole-ivermectin combination \\
\hline 7 & Mane and Angane (2019) ${ }^{98}$ & Cyclopentolate $1 \%$ eye drops induced delirium in a Child \\
\hline 8 & Sharma et al $(2012)^{99}$ & Bath salts-induced delirium \\
\hline \multicolumn{3}{|c|}{ Delirium associated with psychotropics } \\
\hline 9 & Das et al (2019) ${ }^{100}$ & Delirium associated with discontinuation of sertraline in an elderly \\
\hline 10 & Sharma and Aggarwal (2010) $)^{101}$ & $\begin{array}{l}\text { Delirium associated with olanzapine therapy in an elderly male with } \\
\text { bipolar affective disorder }\end{array}$ \\
\hline 11 & Dixit et al $(2015)^{102}$ & $\begin{array}{l}\text { Valproate induced delirium due to hyperammonemia in a case of } \\
\text { acute mania }\end{array}$ \\
\hline 12 & Muraleedharan et al (2015) ${ }^{103}$ & Valproate induced hyperammonemic delirium \\
\hline
\end{tabular}


Table 8 (Continued)

\begin{tabular}{|c|c|c|}
\hline & Study (year) & Findings \\
\hline \multicolumn{3}{|c|}{ Delirium associated with psychotropics } \\
\hline 13 & Pradeep $(2008)^{104}$ & Valproate monotherapy induced-delirium due to hyperammonemia \\
\hline 14 & Khanra et al (2016) ${ }^{105}$ & Unusual case of delirium after restarting clozapine \\
\hline 15 & Ghosh et al (2014) $)^{106}$ & Mirtazapine-associated hyponatremia presenting as delirium \\
\hline 16 & Manjunatha et al $(2011)^{107}$ & $\begin{array}{l}\text { Delayed onset, protracted delirium and aspiration pneumonitis } \\
\text { associated with use of a combination of clozapine and ECT }\end{array}$ \\
\hline 17 & Kumar et al $(2003)^{108}$ & Delirium associated with combination of clozapine and ECT \\
\hline 18 & Sadananda et al (2013) $)^{109}$ & $\begin{array}{l}\text { Delirium during the course of electroconvulsive therapy in a patient } \\
\text { on lithium carbonate treatment }\end{array}$ \\
\hline 19 & Selvaraj and Praharaj (2012) $)^{110}$ & $\begin{array}{l}\text { Delayed onset and prolonged interictal delirium following electro- } \\
\text { convulsive therapy }\end{array}$ \\
\hline 20 & Sarangula et al (2016) $)^{111}$ & $\begin{array}{l}\text { Post injection delirium/sedation syndrome associated with olanzap- } \\
\text { ine depot injection }\end{array}$ \\
\hline 21 & Garg et al (2019) $)^{112}$ & $\begin{array}{l}\text { Delayed onset post injection delirium/sedation syndrome associated } \\
\text { with olanzapine pamoate a case report }\end{array}$ \\
\hline 22 & Punnoose et al (2017) $)^{113}$ & $\begin{array}{l}\text { Low body mass index a risk factor for post-injection delirium/seda- } \\
\text { tion syndrome with depot olanzapine }\end{array}$ \\
\hline 23 & Upadhyay et al (2017) $)^{114}$ & $\begin{array}{l}\text { Post injection delirium/sedation syndrome with long-acting olan- } \\
\text { zapine pamoate }\end{array}$ \\
\hline 24 & Venkatesan et al (2019) $)^{115}$ & $\begin{array}{l}\text { Post-injection delirium/sedation syndrome after 31st long-acting } \\
\text { olanzapine depot injection }\end{array}$ \\
\hline \multicolumn{3}{|c|}{ Delirium associated with alcohol or opioid withdrawal } \\
\hline 25 & Mattoo et al $(2012)^{116}$ & Refractory delirium tremens \\
\hline 26 & Ram et al $(2017)^{117}$ & Lorazepam precipitated alcohol withdrawal delirium \\
\hline 27 & Charan et al $(2011)^{118}$ & $\begin{array}{l}\text { Genital self-mutilation in alcohol withdrawal state complicated with } \\
\text { delirium }\end{array}$ \\
\hline 28 & Saddichha et al $(2008)^{119}$ & Delayed-onset delirium tremens \\
\hline 29 & Talikoti et al (2012) & Delirium tremens with hollow viscus perforation \\
\hline 30 & Das et al $(2005)^{121}$ & $\begin{array}{l}\text { Naltrexone precipitating delirium in a patient with opioid } \\
\text { dependence }\end{array}$ \\
\hline 31 & Das et al $(2017)^{122}$ & Opioid withdrawal presenting as delirium \\
\hline 32 & Sharma et al $(2017)^{123}$ & Opium withdrawal delirium \\
\hline 33 & Raj et al $(2017)^{124}$ & Complicated opioid withdrawal in delirium without convulsions \\
\hline 34 & Ghosh et al $(2013)^{125}$ & Acute delirium due to parenteral tramadol \\
\hline 35 & Narayan et al $(2015)^{126}$ & $\begin{array}{l}\text { Varenicline induced delirium in an alcohol and nicotine dependent } \\
\text { patient }\end{array}$ \\
\hline 36 & Mattoo et al $(2011)^{127}$ & Zolpidem withdrawal delirium \\
\hline 37 & Sharan et al $(2007)^{128}$ & Intoxication delirium associated with zolpidem \\
\hline \multicolumn{3}{|c|}{ Delirium associated with specific physical illnesses } \\
\hline 38 & Padhy et al $(2008)^{129}$ & Delirium in a child with nephrotic syndrome \\
\hline 39 & Manamohan et al $(2017)^{130}$ & Delirium in an elderly with chronic lymphocytic leukemia \\
\hline 40 & Manappallil (2016) ${ }^{131}$ & Delirium in a patient with Parkinson's disease \\
\hline
\end{tabular}


Table 8 (Continued)

\begin{tabular}{|c|c|c|}
\hline & Study (year) & Findings \\
\hline \multicolumn{3}{|c|}{ Delirium associated with specific physical illnesses } \\
\hline 41 & Singh $(2017)^{132}$ & Pancreatic pseudocyst with delirium in an alcohol dependent male \\
\hline 42 & Khanna $(1988)^{133}$ & Hypopituitarism presenting as delirium \\
\hline 43 & Pappachan and Agrawal (2019) ${ }^{134}$ & Postoperative delirium \\
\hline 44 & Nag et al $(2016)^{135}$ & $\begin{array}{l}\text { Sepsis associated delirium mimicking postoperative delirium as the } \\
\text { initial presenting symptom of urosepsis in a patient who underwent } \\
\text { nephrolithotomy }\end{array}$ \\
\hline 45 & Jebaraj et al $(2005)^{136}$ & $\begin{array}{l}\text { Tuberculous meningitis masked by delirium in an alcohol-depend- } \\
\text { ent patient }\end{array}$ \\
\hline 46 & Upadhyaya et al (2011) $)^{137}$ & $\begin{array}{l}\text { Delirium and catatonia in a person with alcohol dependence with } \\
\text { tubercular meningoencephalitis }\end{array}$ \\
\hline 47 & Raina et al (2019) $)^{138}$ & $\begin{array}{l}\text { Hyperactive delirium and bilateral ptosis: bilateral thalamic infarcts } \\
\text { due to artery of Percheron occlusion }\end{array}$ \\
\hline \multicolumn{3}{|c|}{ Prolonged or persistent delirium } \\
\hline 48 & Sireesha et al (2013) & $\begin{array}{l}\text { Prolonged delirium secondary to hypoxic-ischemic encephalopathy } \\
\text { following complete hanging }\end{array}$ \\
\hline 49 & Grover et al $(2014)^{140}$ & Persistent delirium \\
\hline 50 & Thukral et al $(2013)^{141}$ & Conundrum of prolonged delirium \\
\hline \multirow[t]{2}{*}{51} & Achalia et al $(2018)^{142}$ & Protracted delirium tremens \\
\hline & \multicolumn{2}{|l|}{ Delirious mania } \\
\hline 52 & Soni et al $(2015)^{143}$ & Delirious mania in elderly \\
\hline 53 & Chawla et al $(2018)^{144}$ & $\begin{array}{l}\text { Identification and management of "delirious mania": a rare clinical } \\
\text { entity }\end{array}$ \\
\hline \multirow[t]{2}{*}{54} & Bipeta and Khan (2012) ${ }^{145}$ & Delirious mania \\
\hline & \multicolumn{2}{|l|}{ Management of delirium } \\
\hline 55 & Gupta et al $(2004)^{146}$ & Olanzapine for delirium in Parkinsonism \\
\hline 56 & Mahajan et al $(2010)^{147}$ & $\begin{array}{l}\text { Use of propofol as an adjuvant therapy in refractory delirium } \\
\text { tremens }\end{array}$ \\
\hline 57 & Danivas et al $(2010)^{148}$ & Electroconvulsive therapy in the treatment of delirious mania \\
\hline 58 & Narayanaswamy et al (2012) ${ }^{149}$ & Successful use of oxazepam in the treatment of delirium tremens \\
\hline
\end{tabular}

Abbreviation: $\mathrm{ECT}$, electroconvulsive therapy.

been reported that the incidence of emergence agitation is comparable across the use of most flurane anesthetic agents. ${ }^{91}$

\section{Case Reports focusing on Delirium}

A total of 58 case reports/series have focused on delirium as the primary outcome/issue ( - Table 8)..$^{92-149}$ Some of these case reports have reported association of delirium with medications such as levetiracetam, ${ }^{92}$ levofloxacin, ${ }^{93,94}$ fluoroquinolones, ${ }^{95}$ zoledronate, ${ }^{96}$ a combination of albendazole and ivermectin, ${ }^{97}$ and use of cyclopentolate eye drops. ${ }^{98}$ One report presented information about delirium associated with bath salts. ${ }^{99}$ In terms of psychotropics, delirium has been reported with discontinuation of sertraline, ${ }^{100}$ use of olanzapine, ${ }^{101}$ valproate associated hyperammonemia, ${ }^{102-104}$ restarting of clozapine, ${ }^{105}$ mirtazapine associated hyponatremia, ${ }^{106}$ use of a combination of clozapine and electroconvulsive therapy (ECT), ${ }^{107,108}$ use of a combination of lithium and ECT, ${ }^{109,110}$ and postinjection delirium/sedation syndrome associated with olanzapine depot injection. ${ }^{111-115}$ Some of the case reports/case series focus on substance-related delirium, ${ }^{116-128}$ either during the withdrawal phase or intoxication phase. The case reports also cover topics 
like refractory delirium tremens, ${ }^{116}$ delayed onset delirium tremens, ${ }^{119}$ delirium tremens with hollow viscus perforation, ${ }^{120}$ genital self-mutilation in alcohol withdrawal state complicated with delirium, ${ }^{116}$ delirium during opioid withdrawal, ${ }^{122}$ naltrexone precipitating delirium, ${ }^{121}$ delirium due to use of parental tramadol, ${ }^{125}$ varenicline-induced delirium, ${ }^{126}$ and delirium associated with zolpidem withdrawal ${ }^{127}$ or intoxication. ${ }^{128}$ Delirium has also been reported in association with various physical illnesses such as nephrotic syndrome, ${ }^{129}$ chronic lymphocytic leukemia, ${ }^{130}$ Parkinson's disease, ${ }^{131}$ pancreatic pseudocyst, ${ }^{132}$ hypopituitarism, ${ }^{133}$ postoperative state, ${ }^{134}$ sepsis, ${ }^{135}$ tuberculous meningitis, ${ }^{136,137}$ and thalamic infarcts. ${ }^{138}$ One case report has focused on long-standing delirium secondary to hypoxic-ischemic encephalopathy following complete hanging. ${ }^{139}$ Some of the reports have primarily focused on persistent $^{140}$ or prolonged ${ }^{141}$ or protracted delirium ${ }^{142}$ and delirious mania. ${ }^{143-145}$ Only four reports ${ }^{146-149}$ talked about interventions for delirium, with one focusing on the use of oxazepam in the treatment of delirium tremens, ${ }^{149}$ the use of olanzapine for delirium in Parkinsonism, ${ }^{146}$ use of propofol as adjuvant therapy in refractory delirium tremens, ${ }^{147}$ and ECT for management of delirious mania. ${ }^{148}$

\section{Discussion}

This systematic review suggests that there is a limited research on delirium from India. However, a good thing is that in recent times, delirium has received more research attention, compared with about a decade back. This review further suggests that although psychiatrists have performed the majority of research in the area of delirium, in the recent years, other specialists too, especially, anesthetists have also shown interest in delirium and some of the studies have focused on incidence/prevalence of delirium in ICUs, postoperative delirium, ${ }^{32,33}$ and emergent delirium. ${ }^{35,36}$ Another important aspect that is evident from the available literature is that most of the studies have been based on standard evaluation instruments.

Although there are methodological differences across different studies, available data from India suggest that the prevalence and incidence of delirium in various ICUs have varied from 16.1 to 68.2 and 8 to $59.6 \%$, respectively. In terms of specific non-ICU setting, the prevalence rates vary, depending on the study setting. When one compares the incidence and prevalence figures with the available western literature, ${ }^{174}$ it can be said that these figures from India are comparable to those reported from other parts of the globe. Although, no much information is available in terms of the practices to assess delirium and the knowledge about delirium of clinicians from various specialties, few studies which involved clinicians from India, suggest that most of the ICU clinicians do not assess patients for delirium on regular basis and consider the prevalence rates of delirium, especially among those patients on mechanical ventilation to be lower than what is reported in the literature. ${ }^{175}$ Data also suggest that there is a low concordance rate between the diagnosis made by the psychiatrist and other clinicians ${ }^{67}$ and most of the ICU clinicians are aware of the importance of early mobilization of ICU patients but are not able to practice the same due to lack of support staff and safety concerns. ${ }^{69}$ A study, which focused on improving the knowledge of the nurses, showed that it was associated with significant improvement in the knowledge and practice of nurses toward delirium. ${ }^{71}$ Taken together, it can be said that the incidence and prevalence of delirium in various treatment settings in India are high and comparable to the rest of the world. However, many times, clinicians do not focus on this entity due to lack of awareness and do not screen patients for delirium regularly. Accordingly, it can be said that there is a need to improve the knowledge base, awareness, and change in clinical practice to identify delirium and manage the same in the Indian context to reduce the negative impact of the same on the patients and their caregivers. In India, ICU facilities and ventilators are also a scarcity. Accordingly, prevention and early identification of delirium can reduce the duration of ICU stay and the number of days on ventilators. This would help more patients to utilize these scarce resources. Mental health professionals need to play an important role in improving the awareness of other clinicians about delirium. Mental health professionals can train the clinicians and nurses to identify the patients who are at higher risk of delirium, screen patients, if not all inpatients, then patients at high risk for delirium on day-today basis, institute reorientation cues, other behavioral measures, and environmental measures to improve the outcome of patients with delirium.

In terms of mortality, data from India suggest inpatient mortality in patients with delirium is 6.6 to $30.7 \% 12,14,17-20,24-31$ and some data suggest that this mortality rate is more than that seen in patients without delirium. Postdischarge, over 1 to 6 months after discharge, the mortality increases to approximately 15.9 to $34.6 \% .^{13,18,27}$ Considering these, it can be said that there is a need to improve the awareness of clinicians and other medical professionals about the negative impact of delirium on mortality rates. This may be an important motivating factor for clinicians to manage delirium in their patients.

One of the major areas of research on delirium from India is symptom profile and the factor structure of the symptoms. In general, studies involving the patients in the CLP setting suggest that the majority of the patients of delirium have symptoms of attention deficits, disorientation, sleep-wake cycle disturbances, and motor agitation. Studies that have focused on different subgroups suggest that there are minor differences in the symptom profile of patients belonging to different age groups ${ }^{25,37,41,44,49}$ (elderly, adult, and children), different motoric subtypes, ${ }^{29}$ and those with AWD. ${ }^{31}$ Further, when one compares the symptom profile of those reported for patients in CLP setting and the ICUs, it is evident that patients in the CLP setting have a higher frequency of motor agitation, whereas studies in ICUs suggest a higher frequency of motor retardation. ${ }^{15,42,51}$ These differences possibly actually reflect the differences in the study design than the actual difference in the symptom profile. Studies that have evaluated patients in ICUs have focused on all the patients in the ICUs and hence, they are more often able to include hypoactive patients too, 
which form a small proportion of patients referred to the CLP setting. When one compares the data from India, the findings from India align with studies from other parts of the world. ${ }^{176}$

Studies that have evaluated the factor structure of symptoms of delirium suggest that symptoms cluster on to two to three factors. In the majority of these studies, various cognitive symptoms load onto the same factor, the motoric and psychotic symptoms load together, and the third factor consists of language and thought process abnormalities. In general, data suggest that the motoric and psychotic symptoms more consistently load on to the same factor across different studies. These findings are also supported by the existing literature from other parts of the world. ${ }^{177}$

In terms of other research endeavors, occasional studies from India have attempted to validate various instruments used for screening and diagnosing delirium. ${ }^{22,23,52}$ The instruments which have been validated and evaluated for some psychometric properties in studies from India include ICDSC, MDAS, CAM-ICU, DMSS, and development of DMSS-4 item version. Accordingly, this area of research requires a major boost in the form of development of new instruments and validation of other existing instruments. This will possibly help to study delirium in a much better way.

Although alcohol dependence is reported to be one of the major substances of abuse in India, AWD has received limited research attention. In terms of AWD, available data suggest that compared with emergency services treatment only, emergency services plus comprehensive inpatient addiction treatment is associated with fewer relapses. ${ }^{59}$ Based on this, it can be said that there is a need to develop service models, which will have the mechanism of transferring patients of AWD from emergency settings to inpatient settings after initial stabilization.

Available data also suggest that delirium is the most common diagnosis made by the CLP team..$^{62}$ Other studies from India, which have focused on the prevalence of various psychiatric disorders among patients seen in CLP setting, suggest that the prevalence of delirium ranges from 0.2 to $0.53 \%$ in all the admitted patients. ${ }^{178}$ These findings suggest that delirium should form a major focus for CLP training. Further, it can be said that focusing on delirium in undergraduate training can lead to a reduction in stigma associated with psychiatry, in medical professionals.

Some of the available data from India suggest that symptoms of delirium are associated with significant distress in patients and their caregivers. Accordingly, there is a need to develop supportive intervention programs for these patients to minimize the negative impact of delirium on the sufferers and their caregivers.

In terms of intervention, almost all the studies have focused on one or the other pharmacological agents in the prevention and management of delirium. ${ }^{74-78}$ These studies suggest that atypical antipsychotics, like olanzapine, risperidone, and quetiapine, are not inferior to haloperidol in the management of delirium. Data from other countries also support the same. ${ }^{179}$ However, it is important to note that the trials evaluating these molecules are of small sample size and short duration. In terms of prevention, most of the studies have focused on reduction in the incidence of emergent delirium in children receiving flurane anesthesia and these studies suggest that additional use of agents, like ketamine (low and high doses), midazolam, dexmedetomidine, propofol, glycopyrrolate, and bupivacaine are of some benefit.

\section{Limitations of the Literature and Future Directions}

If one looks at the available literature, it is evident that although delirium occurs at the interface of psychiatry and other clinical specialties, in general, there is a lack of interdisciplinary research in this area. Further, there is a lack of multicentric studies on delirium and there are only occasional attempts at collaboration with researchers from other parts of the globe. ${ }^{174}$ Further, only the Indian Psychiatric Society has come up with the management guidelines for delirium, ${ }^{173}$ with none of the other professional associations from India, coming up with any other recommendations on the subject. Keeping this in mind, there is a need to develop collaborations at the institutional level to start multidisciplinary research and also develop collaboration across various institutes. This will not only lead to an improvement in the research output on the subject but will also help in developing intervention models which can be implemented in resource-constrained countries like India. Further, these collaborations will also help to develop instruments that may be more suitable for the Indian setting. Further, forming a multidisciplinary professional society for delirium, like the American Delirium Society and European Delirium Society, can provide a platform for further exchange of ideas and collaborative research.

If one closely examines the available literature from India, except for a few studies, most of the studies have been limited to approximately 100 participants or less. Accordingly, these studies can be considered as underpowered and collaborative research can address this issue further. One of the important examples of delirium research comes from Italy, in which likeminded researchers joined together for the "Delirium Day" research, which focused on point prevalence of delirium in 1,867 elderly patients across 108 acute and 12 rehabilitation wards. ${ }^{180}$ In this study, delirium was assessed across all the centers on the same day. If researchers from India can take a lead from this, doing this kind of research can help in improving the data and understanding about delirium.

Across the globe, nonpharmacological measures are considered to be the first-line management for delirium and a lot of efforts have been made to evaluate various nonpharmacological treatment bundles, such as HELP program and ABCDEF bundle. ${ }^{9,10}$ Available data suggest that these programs are very useful in the prevention, early identification, and management of delirium. ${ }^{7,8}$ However, none of the studies have evaluated the various nonpharmacological measures for the prevention and management of delirium in the Indian setting. This area requires a major boost if we need to improve the outcome of delirium.

One of the major strengths of India is family system. ${ }^{181}$ Whenever a person from the family falls ill, their family is always available to support the person. However, except 
for the occasional study, there is no research from India, as to how we can utilize this asset to improve the outcome of patients with delirium.

One of the major areas of research, which has not caught the attention of researchers from India, is an evaluation of biomarkers of delirium. One of the major risk factors for delirium is dementia. However, this group of patients has also not received any major attention. As the elderly population is on the rise and India is already an aging country, we need to focus on understanding delirium in this group of patients.

\section{Conclusion}

To conclude, this systematic review suggests that although there is limited research on delirium from India, in recent years there is an increase in research output concerning delirium. Available data suggest that most of the studies have focused on the incidence, prevalence, and symptom profile of patients of delirium.

Conflict of Interest

None declared.

\section{References}

1 Grover S, Kate N, Assessment and management of delirium in medical practice. In: Hemanshu Prabhakar, ed. Neurointensive Care. New Delhi, India: Oxford University Press India; 2019

2 Maldonado JR. Neuropathogenesis of delirium: review of current etiologic theories and common pathways. Am J Geriatr Psychiatry 2013;21(12):1190-1222

3 Maldonado JR. Delirium pathophysiology: an updated hypothesis of the etiology of acute brain failure. Int J Geriatr Psychiatry 2018;33(11):1428-1457

4 Mattoo SK, Grover S, Gupta N. Delirium in general practice. Indian J Med Res 2010;131:387-398

5 Redknap C, Kaitiff D. Delirium superimposed on dementia precipitated by an unexpected bladder tumour. BMJ Case Rep 2019;12(9):12

6 Grover S, Kate N. Developments in psychiatry in India. In: Malhotra S, Chakrabarti S, eds. Developments in Psychiatry in India: Clinical, Research and Policy Perspectives. New Delhi, India: Springer India; 2015

7 Barnes-Daly MA, Phillips G, Ely EW. Improving hospital survival and reducing brain dysfunction at seven california community hospitals: implementing pad guidelines via the ABCDEF bundle in 6,064 patients. Crit Care Med 2017;45(2):171-178

8 Hshieh TT, Yang T, Gartaganis SL, Yue J, Inouye SK. Hospital elder life program: systematic review and meta-analysis of effectiveness. Am J Geriatr Psychiatry 2018;26(10):1015-1033

9 Inouye SK, Bogardus ST Jr., Baker DI, Leo-Summers L, Cooney LM Jr; Hospital Elder Life Program. The hospital elder life program: a model of care to prevent cognitive and functional decline in older hospitalized patients. J Am Geriatr Soc 2000;48(12):1697-1706

10 Morandi A, Brummel NE, Ely EW. Sedation, delirium and mechanical ventilation: the 'ABCDE' approach. Curr Opin Crit Care 2011;17(1):43-49

11 Khurana PS, Sharma PSVN, Avasthi A. Prevalence of delirium in geriatric hospitalized general medical population. Indian J Psychiatry 2002;44(1):41-46

12 Grover S, Subodh BN, Avasthi A, et al. Prevalence and clinical profile of delirium: a study from a tertiary-care hospital in north India. Gen Hosp Psychiatry 2009;31(1):25-29
13 Rai D, Garg RK, Malhotra HS, et al. Acute confusional state/ delirium: An etiological and prognostic evaluation. Ann Indian Acad Neurol 2014;17(1):30-34

14 Khurana V, Gambhir IS, Kishore D. Evaluation of delirium in elderly: a hospital-based study. Geriatr Gerontol Int 2011;11(4):467-473

15 Grover S, Ghosh A, Sarkar S, Desouza A, Yaddanapudi LN, Basu D. Delirium in intensive care unit: phenomenology, subtypes, and factor structure of symptoms. Indian J Psychol Med 2018;40(2):169-177

16 Kumar R, Kaur S, Kaur S. ICU delirium and clinical parameters An observational survey. Indian Journal of Psychiatric Nursing. 2016;11:10

17 Grover S, Lahariya S, Bagga S, Sharma A. Incidence, prevalence and risk factors for delirium in elderly admitted to a coronary care unit. Journal of Geriatric Mental Health. 2014;1:45-45

18 Jayaswal AK, Sampath H, Soohinda G, Dutta S. Delirium in medical intensive care units: Incidence, subtypes, risk factors, and outcome. Indian J Psychiatry 2019;61(4):352-358

19 Sharma A, Malhotra S, Grover S, Jindal SK. Incidence, prevalence, risk factor and outcome of delirium in intensive care unit: a study from India. Gen Hosp Psychiatry 2012;34(6):639-646

20 Lahariya S, Grover S, Bagga S, Sharma A. Delirium in patients admitted to a cardiac intensive care unit with cardiac emergencies in a developing country: incidence, prevalence, risk factor and outcome. Gen Hosp Psychiatry 2014;36(2):156-164

21 Bamalwa M, Mahmood SN, Praharaj SK. Delirium in cardiac ICU patients. Ann Clin Psychiatry 2016;28(1):51-55

22 Shyamsundar G, Raghuthaman G, Rajkumar AP, Jacob KS. Validation of memorial delirium assessment scale. J Crit Care 2009;24(4):530-534

23 Barman A, Pradhan D, Bhattacharyya P, et al. Diagnostic accuracy of delirium assessment methods in critical care patients. J Crit Care 2018;44:82-86

24 Grover S, Ghormode D, Ghosh A, et al. Risk factors for delirium and inpatient mortality with delirium. J Postgrad Med 2013;59(4):263-270

25 Grover S, Ghosh A, Kate N, et al. Do motor subtypes of delirium in child and adolescent have a different clinical and phenomenological profile? Gen Hosp Psychiatry 2014;36(2):187-191

26 Grover S, Sahoo S, Chakrabarti S, Avasthi A. Post-traumatic stress disorder (PTSD) related symptoms following an experience of delirium. J Psychosom Res 2019;123:109725

27 Grover S, Shah R, Kr A. [The mortality rate among patients with delirium 6 months after diagnosis by a consultation-liaison psychiatric team] (in Turkish) Turk Psikiyatr Derg 2012;23(3):189-192

28 Grover S, Kate N, Agarwal M, et al. Delirium in elderly people: a study of a psychiatric liaison service in north India. Int Psychogeriatr 2012;24(1):117-127

29 Grover S, Sharma A, Aggarwal M, et al. Comparison of symptoms of delirium across various motoric subtypes. Psychiatry Clin Neurosci 2014;68(4):283-291

30 Grover S, Sharma A, Kate N, et al. Symptom profile and outcome of delirium associated with alcohol withdrawal syndrome: a study from India. Am J Addict 2013;22(5):503-509

31 Grover S, Kate N, Sharma A, et al. Symptom profile of alcohol withdrawal delirium: factor analysis of Delirium Rating Scale-Revised-98 version. Am J Drug Alcohol Abuse 2016;42(2):196-202

32 Dhakharia V, Sinha S, Bhaumik J. Postoperative delirium in Indian patients following major abdominal surgery for cancer: risk factors and associations. Indian J Surg Oncol 2017;8(4):567-572

33 Kumar AK, Jayant A, Arya VK, Magoon R, Sharma R. Delirium after cardiac surgery: a pilot study from a single tertiary referral center. Ann Card Anaesth 2017;20(1):76-82 
34 Chrispal A, Mathews KP, Surekha V. The clinical profile and association of delirium in geriatric patients with hip fractures in a tertiary care hospital in India. J Assoc Physicians India 2010;58:15-19

35 Khanna P, Saini K, Sinha R, Nisa N, Kumar S, Maitra S. Correlation between duration of preoperative fasting and emergence delirium in pediatric patients undergoing ophthalmic examination under anesthesia: a prospective observational study. Paediatr Anaesth 2018;28(6):547-551

36 Sethi S, Ghai B, Ram J, Wig J. Postoperative emergence delirium in pediatric patients undergoing cataract surgery-a comparison of desflurane and sevoflurane. Paediatr Anaesth 2013;23(12):1131-1137

37 Grover S, Chakrabarti S, Shah R, Kumar V. A factor analytic study of the Delirium Rating Scale-Revised-98 in untreated patients with delirium. J Psychosom Res 2011;70(5):473-478

38 Jain G, Chakrabarti S, Kulhara P. Symptoms of delirium: an exploratory factor analytic study among referred patients. Gen Hosp Psychiatry 2011;33(4):377-385

39 Mattoo SK, Grover S, Chakravarty K, Trzepacz PT, Meagher DJ, Gupta N. Symptom profile and etiology of delirium in a referral population in northern india: factor analysis of the DRS-R98. J Neuropsychiatry Clin Neurosci 2012;24(1):95-101

40 Rajlakshmi AK, Mattoo SK, Grover S. Relationship between cognitive and non-cognitive symptoms of delirium. Asian J Psychiatr 2013;6(2):106-112

41 Grover S, Agarwal M, Sharma A, et al. Symptoms and aetiology of delirium: a comparison of elderly and adult patients. East Asian Arch Psychiatry 2013;23(2):56-64

42 Sharma A, Malhotra S, Grover S, Jindal SK. Symptom profile as assessed on delirium rating scale-revised-98 of delirium in respiratory intensive care unit: A study from India. Lung India 2017;34(5):434-440

43 Dhoble P, Vankar GK. Phenomenology of delirium. Archives of Indian Psychiatry 2009;10(1):51-56

44 Grover S, Sharma A, Avasthi A. Motoric subtypes of delirium in geriatric patients. J Geriatr Ment Health. 2014;1:14

45 Grover S, Ghosh A, Ghormode D. Do patients of delirium have catatonic features? An exploratory study. Psychiatry Clin Neurosci 2014;68(8):644-651

46 Grover S, Chakrabarti S, Avasthi A. Influence of preexisting cognitive deficits on symptom profile and motoric subtypes of delirium. J Geriatr Ment Health. 2015;2:83

47 Grover S, Shah R. Perceptions among primary caregivers about the etiology of delirium: a study from a tertiary care centre in India. Afr J Psychiatry (Johannesbg) 2012;15(3):193-195

48 Grover S, Kate N, Mattoo SK, et al. Delirium: predictors of delay in referral to consultation liaison psychiatry services. Indian J Psychiatry 2014;56(2):171-175

49 Grover S, Kate N, Malhotra S, Chakrabarti S, Mattoo SK, Avasthi A. Symptom profile of delirium in children and adolescent-does it differ from adults and elderly? Gen Hosp Psychiatry 2012;34(6):626-632

50 Grover S, Mehra A, Chakrabarti S, Avasthi A. Association of cognitive and noncognitive symptoms of delirium: a study from consultation-liaison psychiatry set-up. J Neurosci Rural Pract 2016;7(suppl 1) :S7-S12

51 Lahariya S, Grover S, Bagga S, Sharma A. Phenomenology of delirium among patients admitted to a coronary care unit. Nord J Psychiatry 2016;70(8):626-632

52 George C, Nair JS, Ebenezer JA, et al. Validation of the intensive care delirium screening checklist in nonintubated intensive care unit patients in a resource-poor medical intensive care setting in South India. J Crit Care 2011;26(2):138-143

53 Grover S, Ghosh A, Ghormode D. Experience in delirium: is it distressing? J Neuropsychiatry Clin Neurosci 2015;27(2):139-146
54 Kumar A, Bakhla AK, Gupta S, Raju BMSVK, Prasad A. Etiologic and cognitive differences in hyperactive and hypoactive delirium. Prim Care Companion CNS Disord 2015;17(6):17

55 Mushtaq R, Shoib S, Shah T, Dar MM, Mushtaq S. Recognizing changes in cognition in sub types of acute confusional state. J Clin Diagn Res 2014;8(7):MC01-MC03

56 Grover S, Sarkar S, Yaddanapudi LN, Ghosh A, Desouza A, Basu D. Intensive care unit delirium: a wide gap between actual prevalence and psychiatric referral. J Anaesthesiol Clin Pharmacol 2017;33(4):480-486

57 Mohan KP, Kiran SP, Madhavi K. A study of phenomenology of delirium in patients with and without neuroimaging changes. Archives of Mental Health. 2015;16:129

58 Sarkar S, Choudhury S, Ezhumalai G, Konthoujam J. Risk factors for the development of delirium in alcohol dependence syndrome: clinical and neurobiological implications. Indian J Psychiatry 2017;59(3):300-305

59 Baby S, Murthy P, Thennarasu K, Chand PK, Viswanath B. Comparative outcome in patients with delirium tremens receiving care in emergency services only versus those receiving comprehensive inpatient care. Indian J Psychiatry 2017;59(3):293-299

60 Malhotra S, Basu D, Ghosh A, Khullar M, Chugh N, Kakkar N. An exploratory study of candidate gene(s) for delirium tremens: adding the new cholinergic dimension to the conundrum. Asian J Psychiatr 2018;31:137-141

61 Prinka, Sharma A. Comparative study of delirium in emergency and consultation liaison- a tertiary care hospital based study in Northern India. J Clin Diagn Res 2016;10:VC01-VC05

62 Grover S, Sahoo S, Aggarwal S, Dhiman S, Chakrabarti S, Avasthi A. Reasons for referral and diagnostic concordance between physicians/surgeons and the consultation-liaison psychiatry team: An exploratory study from a tertiary care hospital in India. Indian J Psychiatry 2017;59(2):170-175

63 Grover S, Malhotra S, Bharadwaj R, Bn S, Kumar S. Delirium in children and adolescents. Int $\mathrm{J}$ Psychiatry Med 2009;39(2):179-187

64 Grover S, Mattoo SK, Aarya KR, et al. Replication analysis for composition of the delirium motor subtype scale (DMSS) in a referral cohort from Northern India. Psychiatry Res 2013;206(1):68-74

65 Meagher D, Adamis D, Leonard M, et al. Development of an abbreviated version of the delirium motor subtyping scale (DMSS-4) Int Psychogeriatr 2014;26(4):693-702

66 Gupta N, Sharma P, Meagher D. Predictors of delayed identification of delirium in a general hospital liaison psychiatry service: a study from North India. Asian J Psychiatr 2010;3(1):31-32

67 Meagher DJ, Morandi A, Inouye SK, et al. Concordance between DSM-IV and DSM-5 criteria for delirium diagnosis in a pooled database of 768 prospectively evaluated patients using the delirium rating scale-revised-98. BMC Med 2014;12:164

68 Khurana PS, Sharma PSVN, Avasthi A. Risk factors in delirious geriatric general medical inpatients. Indian J Psychiatry 2002;44(3):266-272

69 Chawla R, Myatra SN, Ramakrishnan N, Todi S, Kansal S, Dash SK. Current practices of mobilization, analgesia, relaxants and sedation in Indian ICUs: a survey conducted by the Indian Society of Critical Care Medicine. Indian J Crit Care Med 2014;18(9):575-584

70 Morandi A, Piva S, Ely EW, et al. Worldwide survey of the "Assessing Pain, Both Spontaneous Awakening and Breathing Trials, Choice of Drugs, Delirium Monitoring/Management, Early Exercise/Mobility, and Family Empowerment" (ABCDEF) bundle. Crit Care Med 2017;45(11):e1111-e1122

71 Varghese NC, Macaden L, Premkumar B, Mathews P, Kumar S. Delirium in older people in hospital: an education programme. Br J Nurs 2014;23(13):704-709 
72 Grover S, Shah R. Distress due to delirium experience. Gen Hosp Psychiatry 2011;33(6):637-639

73 Grover S, Shah R. Delirium-related distress in caregivers: a study from a tertiary care centre in India. Perspect Psychiatr Care 2013;49(1):21-29

74 Jain R, Arun P, Sidana A, Sachdev A. Comparison of efficacy of haloperidol and olanzapine in the treatment of delirium. Indian J Psychiatry 2017;59(4):451-456

75 Grover S, Mahajan S, Chakrabarti S, Avasthi A. Comparative effectiveness of quetiapine and haloperidol in delirium: a single blind randomized controlled study. World J Psychiatry 2016;6(3):365-371

76 Grover S, Kumar V, Chakrabarti S. Comparative efficacy study of haloperidol, olanzapine and risperidone in delirium. J Psychosom Res 2011;71(4):277-281

77 Gupta N, Sharma P, Mattoo SK. Effectiveness of risperidone in delirium. Can J Psychiatry 2005;50(1):75

78 Vijayakumar HN, Ramya K, Duggappa DR, et al. Effect of melatonin on duration of delirium in organophosphorus compound poisoning patients: a double-blind randomised placebo controlled trial. Indian J Anaesth 2016;60(11):814-820

79 Avidan MS, Maybrier HR, Abdallah AB, et al; PODCAST Research Group. Intraoperative ketamine for prevention of postoperative delirium or pain after major surgery in older adults: an international, multicentre, double-blind, randomised clinical trial. Lancet 2017;390(10091):267-275

80 Gonsalvez G, Baskaran D, Upadhyaya V. Prevention of emergence delirium in children - a randomized study comparing two different timings of administration of midazolam. Anesth Essays Res 2018;12(2):522-527

81 Makkar JK, Jain D, Jain K, Jafra A. Dexmedetomidine and emergence agitation. Anaesthesia 2015;70(7):883-884

82 Trivedi S, Kumar R, Tripathi AK, Mehta RK. A comparative study of dexmedetomidine and midazolam in reducing delirium caused by ketamine. J Clin Diagn Res 2016;10(8):UC01-UC04

83 Prabhu MK, Mehandale SG. Comparison of oral dexmedetomidine versus oral midazolam as premedication to prevent emergence agitation after sevoflurane anaesthesia in paediatric patients. Indian J Anaesth 2017;61(2):131-136

84 Sinha A, Sood J. Caudal block and emergence delirium in pediatric patients: Is it analgesia or sedation. ? Saudi J Anaesth 2012;6(4):403-407

85 Perumal DK, Adhimoolam M, Selvaraj N, Lazarus SP, Mohammed MAR. Midazolam premedication for Ketamine-induced emergence phenomenon: a prospective observational study. J Res Pharm Pract 2015;4(2):89-93

86 Mukherjee A, Das A, Basunia SR, Chattopadhyay S, Kundu R, Bhattacharyya R. Emergence agitation prevention in paediatric ambulatory surgery: a comparison between intranasal dexmedetomidine and clonidine. J Res Pharm Pract 2015;4(1):24-30

87 Begum U, Singh PR, Naithani B, Singh V, Singh GP, Tiwari T. Dexmedetomidine as bolus or low-dose infusion for the prevention of emergence agitation with sevoflurane anesthesia in pediatric patients. Anesth Essays Res 2019;13(1):57-62

88 Shenoy U, Peter V, Mathew P, Thomas T. Transversus abdominis plane block supplementation during iliac crest bone graft harvesting - effect on postoperative pain. J Anaesthesiol Clin Pharmacol 2018;34(4):472-477

89 Priye S, Jagannath S, Singh D, Shivaprakash S, Reddy DP. Dexmedetomidine as an adjunct in postoperative analgesia following cardiac surgery: a randomized, double-blind study. Saudi J Anaesth 2015;9(4):353-358

90 Sharma K, Kumar M, Gandhi R. Effect of single-dose dexmedetomidine on intraoperative hemodynamics and postoperative recovery during pediatric adenotonsillectomy. Anesth Essays Res 2019;13(1):63-67

91 Singh R, Kharbanda M, Sood N, Mahajan V, Chatterji C. Comparative evaluation of incidence of emergence agitation and post-operative recovery profile in paediatric patients after isoflurane, sevoflurane and desflurane anaesthesia. Indian J Anaesth 2012;56(2):156-161

92 Kasim S, PV I, KP J, Prabhakaran A. Levetiracetam as a cause of delirium in elderly patient: a case report. Kerala Journal of Psychiatry. 2019;31:18-22

93 Ghoshal A, Damani A, Salins N, Deodhar J, Muckaden MA. Management of levofloxacin induced anaphylaxis and acute delirium in a palliative care setting. Indian J Palliat Care 2015;21(1):76-78

94 Raj V, Murthy TVSP. Levofloxacin induced delirium with psychotic features in a young patient. Med J Armed Forces India 2013;69(4):404-405

95 Chowdhry V, Padhi M, Mohanty BB, Mohapatra S. Fluoroquinolones: An under-recognized cause for delirium. J Anaesthesiol Clin Pharmacol 2015;31(3):410-411

96 Nasiruddin M, Fayazuddin M, Zahid M, Iftekhar S. Acute delirium in an elderly woman following zoledronate administration. J Pharmacol Pharmacother 2014;5(3):217-219

97 Kaur U, Chakrabarti SS, Gambhir IS. Delirium induced by albendazole-ivermectin combination: report of the first case in an older patient. Geriatr Gerontol Int 2017;17(12):2618-2620

98 Mane A, Angane A. Cycloplegic eye drop-induced delirium in a child. Ann Indian Psychiatry. 2019;3:182

99 Sharma TR, Iskandar JW, Ali R, Shah UR. Bath salts-induced delirium and brief psychotic episode in an otherwise healthy young man. Prim Care Companion CNS Disord 2012;14(2):14

100 Das S, Kumar M, Sahotra A. Delirium associated with discontinuation of sertraline in an elderly. Indian J Psychiatry 2019;61(6):660-661

101 Sharma RC, Aggarwal A. Delirium associated with olanzapine therapy in an elderly male with bipolar affective disorder. Psychiatry Investig 2010;7(2):153-154

102 Dixit S, Namdeo M, Azad S. Valproate induced delirium due to hyperammonemia in a case of acute mania: a diagnostic dilemma. J Clin Diagn Res 2015;9(4):VD01-VD02

103 Muraleedharan A, Palappallil DS, Gangadhar R, Das S. Valproate induced hyperammonemic delirium. J Clin Diagn Res 2015;9(12):FR01-FR03

104 Pradeep RJ. Valproate monotherapy induced-delirium due to hyperammonemia: A report of three adult cases with different types of presentation. Indian J Psychiatry 2008;50(2):121-123

105 Khanra S, Sethy RR, Munda SK, Khess CRJ. An unusual case of delirium after restarting clozapine. Clin Psychopharmacol Neurosci 2016;14(1):107-108

106 Ghosh A, Hegde A, Grover S. Mirtazapine-associated hyponatremia presenting as delirium. Indian J Pharmacol 2014;46(4):448-449

107 Manjunatha N, Ram Kumar GS, Vidyendaran R, Muralidharan K, John JP. Delayed onset, protracted delirium and aspiration pneumonitis associated with a combination of clozapine and electroconvulsive therapy. Indian J Psychol Med 2011;33(1):80-82

108 Kumar S, Goswami U, Behera D, Khastgir U. ECT and clozapine combination producing delirium : a case report. Indian J Psychiatry 2003;45(3):193

109 Sadananda SK, Narayanaswamy JC, Srinivasaraju R, Math $\mathrm{SB}$. Delirium during the course of electroconvulsive therapy in a patient on lithium carbonate treatment. Gen Hosp Psychiatry 2013;35(6):678.e1-678.e2

110 Selvaraj AG, Praharaj SK. Delayed onset and prolonged interictal delirium following electroconvulsive therapy. Psychogeriatrics 2012;12(3):211-213

111 Sarangula SM, Mythri SV, Sanjay Y, Reddy MS. Postinjection delirium/sedation syndrome with olanzapine depot injection. Indian J Psychol Med 2016;38(4):366-369

112 Garg S, Gupta D, Rakesh K, Tikka SK. Delayed onset postinjection delirium/sedation syndrome 
associated with olanzapine pamoate: a case report. J Clin Psychopharmacol 2019;39(5):523-524

113 Punnoose ZM, Ramamurthy P, Solomon S. Is low body mass index a risk factor for postinjection delirium/sedation syndrome? Indian J Psychol Med 2017;39(3):380

114 Upadhyay A, Bhandari SS, Sharma V, Das S. Postinjection delirium/sedation syndrome with long-acting olanzapine pamoate in a middle-aged female. Indian $\mathrm{J}$ Psychiatry 2017;59(4):517-519

115 Venkatesan V, Khanra S, Mandal K, Deepak MB. Postinjection delirium/sedation syndrome after 31st long-acting olanzapine depot injection. Clin Neuropharmacol 2019;42(2):64-65

116 Mattoo SK, Kate N, Verma AK. Refractory delirium tremens: a case report and brief review. Innov Clin Neurosci 2012;9(3):19-22

117 Ram D, Raman R, Gowdappa B. Lorazepam precipitated alcohol withdrawal delirium - two case report. Asian J Psychiatr 2017;30:98-99

118 Charan SH, Reddy CMPK. Genital self mutilation in alcohol withdrawal state complicated with delirium. Indian J Psychol Med 2011;33(2):188-190

119 Saddichha S, Manjunatha N, Prasad Sinha BN, Khess CRJ. Delayed-onset delirium tremens - a diagnostic and management challenge. Acta Neuropsychiatr 2008;20(3):152-156

120 Talikoti AT, Sindhu B, Kavyashree S, Kumar KK. Alcoholic delirium tremens with hollow viscus perforation scheduled for emergency laparotomy. Indian J Anaesth 2012;56(2):189-192

121 Das PP, Grover S, Kumar S. Naltrexone-precipitated delirium. Ger J Psychiatry 2005;8:101-103

122 Das S, Sah D, Nandi S, Das P. Opioid withdrawal presenting as delirium and role of buprenorphine: a case series. Indian J Psychol Med 2017;39(5):665-667

123 Sharma RC, Kumar R, Sharma DD, Kanwar P. Opium withdrawal delirium: two case reports. Psychopharmacol Bull 2017;47(1):48-51

124 Raj BN, Manamohan N, Hegde D, Huded CB, Pradeep J. A rare case of complicated opioid withdrawal in delirium without convulsions. Indian J Psychol Med 2017;39(2):191-193

125 Ghosh S, Mondal SK, Bhattacharya A, Saddichha S. Acute delirium due to parenteral tramadol. Case Rep Emerg Med 2013;2013:492685

126 Narayan AL, Virupaksha HS, Thejaswi G, Saraswathy GR, Madhavan V, Thyloth M. A case report on varenicline induced delirium in an alcohol and nicotine dependent patient. Indian J Psychol Med 2015;37(3):355-357

127 Mattoo SK, Gaur N, Das PP. Zolpidem withdrawal delirium. Indian J Pharmacol 2011;43(6):729-730

128 Sharan P, Bharadwaj R, Grover S, Padhy SK, Kumar V, Singh J. Dependence syndrome and intoxication delirium associated with zolpidem. Natl Med J India 2007;20(4):180-181

129 Padhy SK, Malhotra S, Kumar V. Identification and management of delirium in a preschooler with nephrotic syndrome. J Indian Assoc Child Adolesc Ment Health. 2008;4:71-72

130 Manamohan N, Raj BN, Hegde D, Pradeep J.. An unusual presentation of chronic lymphocytic leukaemia as delirium. Archives of Mental Health. 2017;18-144

131 Manappallil RG. Delirium in Parkinson's disease: a cocktail diagnosis. J Clin Diagn Res 2016;10(12):OD15-OD16

132 Singh GP. Pseudocyst pancreas with delirium in a married alcohol dependent male: a rare presentation. Indian J Psychol Med 2017;39(2):196-198

133 Khanna S, Ammini A, Saxena S, Mohan D. Hypopituitarism presenting as delirium. Int J Psychiatry Med 1988;18(1):89-92

134 Pappachan B, Agrawal R. Post-operative delirium. J Maxillofac Oral Surg 2019;18(1):157-158

135 Nag DS, Chatterjee A, Samaddar DP, Singh H. Sepsis associated delirium mimicking postoperative delirium as the initial presenting symptom of urosepsis in a patient who underwent nephrolithotomy. World J Clin Cases 2016;4(5):130-134

136 Jebaraj P, Oommen M, Thopuram P, Jacob KS. Tuberculous meningitis masked by delirium in an alcohol-dependent patient: a case report. Acta Psychiatr Scand 2005;112(6):478-479, discussion 480

137 Upadhyaya SK, Pathania M, Sharma A. Multiple-etiology delirium and catatonia in an alcoholic with tubercular meningoencephalitis. Ind Psychiatry J 2011;20(2):139-141

138 Raina S, Thakur A, Sharma R, Sharma A. Hyperactive delirium and bilateral ptosis: bilateral thalamic infarcts due to artery of Percheron occlusion. J Assoc Physicians India 2019;67(12):77-78

139 Sireesha SR, Boorla V, Bhogaraju A. Prolonged delirium secondary to hypoxic ischemic encephalopathy following complete hanging. Archives of Mental Health. 2013;14:174

140 GroverS,MehraA,SurendranI,SuriV...Misseddiagnosis-persistent delirium. J Geriatr Ment Health. 2014;1-118

141 Thukral P, Sonavane S, Shah N, Kalra G, Desousa A. The conundrum of prolonged delirium. Natl Med J India 2013;26(3):150-151

142 Achalia R, Korhale D, Lakkas Y, Mehta UM. Protracted delirium tremens and the forgotten cation: a case report. Asian J Psychiatr 2018;38:29-30

143 Soni R, Khurana H, Tiwari S. Delirious mania in geriatric age: a rare presentation. J Geriatr Ment Health. 2015;2:112

144 Chawla N, Yadav P, Pattanayak RD, Khandelwal SK. Identification and management of "delirious mania:" a rare clinical entity. Ind Psychiatry J 2018;27(1):151-153

145 Bipeta R, Khan MA. Delirious mania: can we get away with this concept? A case report and review of the literature. Case Rep Psychiatry 2012;2012:720354

146 Gupta N, Sharma P, Prabhakar S. Olanzapine for delirium in parkinsonism: therapeutic benefits in lieu of adverse consequences. Neurol India 2004;52(2):274-275

147 Mahajan R, Singh R, Bansal PD, Bala R. Use of propofol as adjuvant therapy in refractory delirium tremens. Ind Psychiatry J 2010;19(1):58-59

148 Danivas V, Behere RV, Varambally S, Rao NP, Venkatasubramanian G, Gangadhar BN. Electroconvulsive therapy in the treatment of delirious mania: a report of 2 patients. J ECT 2010;26(4):278-279

149 Narayanaswamy JC, Viswanath B, Nagpal K, Gopinath S, Math SB, Chandrasekhar CR. Successful use of oxazepam in the treatment of delirium tremens. Prim Care Companion CNS Disord 2012;14(6):14

150 Reddy SV, Irkal JN, Srinivasamurthy A. Postoperative delirium in elderly citizens and current practice. J Anaesthesiol Clin Pharmacol 2017;33(3):291-299

151 Grover S, Ghosh A. Delirium tremens: assessment and management. J Clin Exp Hepatol 2018;8(4):460-470

152 Grover S, Kate N. Assessment scales for delirium: a review. World J Psychiatry 2012;2(4):58-70

153 Grover S, Mattoo SK, Gupta N. Usefulness of atypical antipsychotics and choline esterase inhibitors in delirium: a review. Pharmacopsychiatry 2011;44(2):43-54

154 Vijayakumar B, Elango P, Ganessan R. Post-operative delirium in elderly patients. Indian J Anaesth 2014;58(3):251-256

155 Pinto C. Indian research on acute organic brain syndrome: delirium. Indian J Psychiatry 2010;52(suppl 1) :S139-S147

156 Mehrotra S. Postoperative anaesthetic concerns in children: Postoperative pain, emergence delirium and postoperative nausea and vomiting. Indian J Anaesth 2019;63(9):763-770

157 Mahajan S. Handling delirium on call. Ann Indian Psychiatry. 2019;3:184

158 Routray SS, Swain SP, Choudhury PC. Delirium in critical care. Orissa Journal of Psychiatry. 2011;18:14-22 
159 Mahawer B, Suthar N. Postoperative delirium in total joint arthroplasty patients. Gen Hosp Psychiatry 2017;48:75

160 Kumar P, Khurana H, Kumar A, Sethi S. Letter to editor regarding "comparison of efficacy of haloperidol and olanzapine in the treatment of delirium" Indian J Psychiatry 2019;61(2):218-219

161 Shaji KS, Jyothi KS. Clinical recognition of delirium. Indian J Psychiatry 2014;56(3):306

162 Nair A. [Pharmacogenomics of sevoflurane: role in emergence delirium] (in Portuguese) Rev Bras Anestesiol 2019;69(4):423

163 Shubhakaran, Khichar RJ. Delirium in geriatric patients in perioperative period-Indian perspective. J Assoc Physicians India 2010;58:715-, author reply 715-716

164 Agarwal M, Grover S. Evaluation of delirium in the elderly: needs further evaluation. Geriatr Gerontol Int 2012;12(1):171

165 Grover S, Chakrabarti S. Controlled trials of delirium. J Psychosom Res 2012;72:86

166 GroverS,MattooSK,GuptaN.Evidenceforpharmacologicalmanagement in delirium. Pharmacopsychiatry 2012;45:164-165

167 Chadda RK, Deb KS, Mahapatra A, Gupta R. Referral patterns in a consultation liaison psychiatry service in India: a comparison with the Western world. Gen Hosp Psychiatry 2019;59:76-77

168 Magoon R, Kumar AK, Malik V, Makhija N. Dexmedetomidine and postoperative delirium: decoding the evidence! J Anaesthesiol Clin Pharmacol 2020;36(1):140-141

169 Gupta N. Delirium: another factor when considering type of anesthetic for hip fracture surgery in adults. BMJ 2014;349:g4871

170 Grover S, Kate N. How can we avoid delay in referrals of patients with delirium. ? Indian J Psychiatry 2014;56(3):309-310
171 Macharouthu AV. Delirium: need for cultural change. TJP 2015;1:7-8

172 Grover S. Delirium-most prevalent mental disorder: still a clinical orphan? J Geriatr Ment Health. 2014;1:57

173 Grover S, Avasthi A. Clinical practice guidelines for management of delirium in elderly. Indian J Psychiatry 2018;60(suppl 3) :S329-S340

174 Salluh JI, Soares M, Teles JM, et al; Delirium Epidemiology in Critical Care Study Group. Delirium epidemiology in critical care (DECCA): an international study. Crit Care 2010;14(6):R210

175 Ely EW, Shintani A, Truman B, et al. Delirium as a predictor of mortality in mechanically ventilated patients in the intensive care unit. JAMA 2004;291(14):1753-1762

176 Girard TD, Pandharipande PP, Ely EW. Delirium in the intensive care unit. Crit Care 2008;12(Suppl 3) :S3

177 Thurber S, Kishi Y, Trzepacz PT, et al. Confirmatory factor analysis of the delirium rating scale revised-98 (DRS-R98) J Neuropsychiatry Clin Neurosci 2015;27(2):e122-e127

178 Dua D, Grover S. Profile of patients seen in consultation-liasion psychiatry in India: a review. Indian $\mathrm{J}$ Psychol Med 2019;42(6):503-512

179 Markowitz JD, Narasimhan M. Delirium and antipsychotics: a systematic review of epidemiology and somatic treatment options. Psychiatry (Edgmont Pa) 2008;5(10):29-36

180 Bellelli G, Morandi A, Di Santo SG, et al; Italian Study Group on Delirium (ISGoD). "Delirium Day": a nationwide point prevalence study of delirium in older hospitalized patients using an easy standardized diagnostic tool. BMC Med 2016;14:106

181 Avasthi A. Preserve and strengthen family to promote mental health. Indian J Psychiatry 2010;52(2):113-126 